\title{
Pantoea agglomerans: a mysterious bacterium of evil and good. Part IV. Beneficial effects
}

\author{
Jacek Dutkiewicz', Barbara Mackiewicz², Marta Kinga Lemieszek ${ }^{3}$, Marcin Golec', \\ Janusz Milanowski \\ ${ }^{1}$ Department of Biological Health Hazards and Parasitology, Institute of Rural Health, Lublin, Poland \\ 2 Department of Pneumonology, Oncology and Allergology, Medical University, Lublin, Poland \\ ${ }^{3}$ Department of Medical Biology, Institute of Rural Health, Lublin, Poland
}

Dutkiewicz J, Mackiewicz B, Lemieszek MK, Golec M, Milanowski J. Pantoea agglomerans: a mysterious bacterium of evil and good. Part IV. Beneficial effects. Ann Agric Environ Med. 2016; 23(2): 206-222. doi: 10.5604/12321966.1203879

\begin{abstract}
Ibstract
Pantoea agglomerans, a gammaproteobacterium of plant origin, possesses many beneficial traits that could be used for the prevention and/or treatment of human and animal diseases, combating plant pathogens, promotion of plant growth and bioremediation of the environment. It produces a number of antibiotics (herbicolin, pantocins, microcin, agglomerins, andrimid, phenazine, among others) which could be used for combating plant, animal and human pathogens or for food preservation. Japanese researchers have demonstrated that the low-molecular-mass lipopolysaccharide of $P$. agglomerans isolated by them and described as 'Immunopotentiator from Pantoea agglomerans 1 (IP-PA1)' reveals the extremely wide spectrum of healing properties, mainly due to its ability for the maintenance of homeostasis by macrophage activation. IP-PA1 was proved to be effective in the prevention and treatment of a broad range of human and animal disorders, such as tumours, hyperlipidaemia, diabetes, ulcer, various infectious diseases, atopic allergy and stress-induced immunosuppression; it also showed a strong analgesic effect. It is important that most of these effects could be achieved by the safe oral administration of IP-PA1. Taking into account that $P$. agglomerans occurs commonly as a symbiont of many species of insects, including mosquitoes transmitting the Plasmodium parasites causing malaria, successful attempts were made to apply the strategy of paratransgenesis, in which bacterial symbionts are genetically engineered to express and secrete anti-Plasmodium effector proteins. This strategy shows prospects for a successful eradication of malaria, a deadly disease killing annually over one million people, as well as of other vector-borne diseases of humans, animals and plants. Pantoea agglomerans has been identified as an antagonist of many plant pathogens belonging to bacteria and fungi, as a result of antibiotic production, competition mechanisms or induction of plant resistance. Its use as a biocontrol agent permits the decrease of pesticide doses, being a healthy and environmental-friendly procedure. The application of the preparations of this bacterium efficiently protects the stored pome, stone and citrus fruits against invasion of moulds. P. agglomerans strains associated with both rhizosphere and plant tissues (as endophytes) efficiently promote the growth of many plants, including rice and wheat, which are the staple food for the majority of mankind. The promotion mechanisms are diverse and include fixation of atmospheric nitrogen, production of phytohormones, as well as degradation of phytate and phosphate solubilizing which makes the soil phosphorus available for plants. Accordingly, P. agglomerans is regarded as an ideal candidate for an environmental-friendly bioinoculant replacing chemical fertilizers. It has been documented that the Pantoea strains show biodegradation activity on various chemical pollutants of soil and water, including petroleum hydrocarbons and toxic metals. P. agglomerans prevents the penetration of harmful industrial contaminants into deeper parts of soil by biofilm formation, and has an ability to produce hydrogen from waste. Thus, this bacterium appears as a valuable bioremediator which, in some cases, may be acquired as a cheap form of energy. In conclusion, in spite of the proven pathologic role of P. agglomerans in causing occupational diseases of allergic and/or immunotoxic background and accidental infections, the beneficial traits of this species, and of related species of Pantoea genus, are of great value for potential use in many areas of biotechnology. Hence, any restrictions on the use of these organisms and their products should be declined, providing safety precautions at work with the Pantoea biopreparations are maintained.
\end{abstract}

\section{Key words}

Pantoea agglomerans, beneficial effects, LPS, immunostimulation, treatment of tumors, healing properties, vector-borne diseases, paratransgenesis, biocontrol of plant pathogens, antibiotics, plant growth promotion, bioremediation

\section{Introduction}

In preceding articles on Pantoea agglomerans $[1,2,3]$, the deleterious effects of this bacterium were reviewed, including allergenic and immunotoxic effects associated with occupational exposure to organic dusts, as well as

Address for correspondence: Prof. Jacek Dutkiewicz, Department of Biological Health Hazards and Parasitology, Institute of Rural Health, Jaczewskiego 2, 20-090 Lublin, Poland

E-mail: dutkiewicz.jacek@imw.lublin.pl

Received: 08 March 2016; accepted: 20 April 2016 opportunistic infections of humans and plant diseases. However, the pathogenic properties of this bacterium are counterbalanced by the unbelievable beneficial traits exhibited by $P$. agglomerans, and the closely related species of Pantoea genus that could collectively be described as 'Pantoea agglomerans sensu lato'. On the one hand, this group of bacteria is versatile and diverse, but on the other hand, exhibits some common traits associated with an extremely strange biochemical activity and incredible ability of adaptation to a broad range of hosts and various environmental conditions $[4,5,6]$. This creates a unique opportunity for biotechnology 
to use P. agglomerans as an effective drug, biocontrol agent, biofertilizer or bioremediator. It is fascinating that some potentially pathogenic traits of $P$. agglomerans, such as an ability to activate human macrophages causing lung inflammation $[1,2]$, or an ability to regulate various plantpathogenic functions of bacterial organisms, depending on population density, known as quorum sensing [7], could be efficiently used for the treatment of human diseases [8] or promotion of plant growth [9], respectively. Below are reviewed the most important beneficial traits of $P$. agglomerans that could be used for the protection of the health of humans, animals and plants, as well as for the marked increase in food supply and sanitation of the human living environment.

\section{Antibiotic production}

P. agglomerans has been shown to have unique metabolic capabilities, including antibiotic biosynthesis [10]. These antibiotics could be used for combating plant, animal and human pathogens or for food preservation. They include: • lipopeptide antibiotics - herbicolin A and B, which are active against sterol-containing fungi $[11,12]$; the dapdiamide antibiotic - herbicolin I, produced by $P$. agglomerans and closely related species Pantoea vagans, active against Erwinia amylovora, a pathogen of apple and pear trees [13]; • pantocins $A$ and $B$ inhibiting growth of various Enterobacteriaceae strains, including E. amylovora [14]; • the peptide antibiotic called microcin produced by $P$. agglomerans strain Eh252, targeting also E. amylovora [15]; • the acidic antibiotics called agglomerins A, B, C and D which are moderately active against a wide variety of anaerobic bacteria (including Clostridium difficile, C. perfringens, Propionibacterium acnes) and weakly active against aerobic Gram-positive bacteria (including Streptococcus pyogenes, S. pneumoniae) [16]; • the pseudopeptide antibiotic andrimid which is active against both Gram-negative and Gram-positive bacteria, including methicyllin-resistant Staphylococcus aureus (MRSA), vancomycin-resistant Enterococcus (VRE) and Klebsiella pneumoniae, and displays also limited antiproliferative activity against human tumor cell lines [17]; • the broadspectrum peptide antibiotic 2-amino-3-(oxirane-2,3dicarboxamido)-propanoyl-valine (APV) produced by $P$. agglomerans strain $\mathrm{Pa} 48 \mathrm{~b}$ which was proved to suppress E. amylovora, the soybean pathogen Pseudomonas syringae pv. (pathovar) glycinea, the agent of crown gall disease in many plants Agrobacterium tumefaciens and the human pathogen Candida albicans [18]; • multiple antibiotics produced by a clinical isolate $P$. agglomerans Tx10, that target E. amylovora and clinically relevant pathogens, including Staphylococcus aureus, Streptococcus epidermidis, and Escherichia coli [10]; • D-alanylgriseoluteic acid (AGA), a potent phenazine antibiotic produced by $P$. agglomerans strain Eh1087 which reveals a broad spectrum of antimicrobial activity and is particularly active against Gram-positive pathogens, such as Streptococcus pneumoniae $[19,20]$; • the recently isolated in Korea phenazine antibiotic from $P$. agglomerans apple strain R190, active against various spoilage bacteria, including Pectobacterium carotovorum subsp. carotovorum, Clavibacter michiganensis, and Burkholderia andropogonis, as well as against foodborne pathogens such as Escherichia coli O157:H7 and Salmonella enterica, and other human pathogens such as Klebsiella pneumoniae and Yersinia enterocolitica [21].

\section{Tumour treatment with Pantoea agglomerans LPS preparation: the Japanese scientists pave the way for efficient therapy}

The first systematic use of bacterial products for the treatment of malignant tumors was begun in 1891 by William B. Coley (1862-1936), the creator of Coley's Toxin (Streptococcus combined with Serratia marcescens). Coley postulated that bacterial products stimulate human's immunity to suppress tumours, and hence he is known as a 'Father of Immunotherapy' [22]. About a hundred years later, his ideas were revived by a group of Japanese scientists $[23,24,25,26,27$, 28 . They noticed that the extract of wheat flour revealed antitumour effects, and after detailed analysis determined that these effects are due to the presence of Pantoea agglomerans $[23,26]$, the organism commonly associated with grain and flour [2]. Consequently, the Japanese researchers isolated and purified the active substance which was the low-molecularmass $(5 \mathrm{kDa})$ lipopolysaccharide (LPS) of P. agglomerans [26], later defined by them as 'LPSp' [25] or 'Immunopotentiator from Pantoea agglomerans 1 (IP-PA1)’ [28]. Mizuno and Soma [29] described this new preparation as a 'nontoxic type of Coley's toxin', which could be efficiently used for the treatment of cancer and multiple intractable diseases via oral or percutaneous route, without any side-effects.

Iwamoto et al. [25] demonstrated that intradermal administration of $P$. agglomerans LPS (LPSp) to mice in combination with cyclophosphamide resulted in the complete regression of MH134 haepatoma tumour. They observed in treated mice an extensive necrosis and marked infiltrations of inflammatory cells (CD4+ and CD8+ T-lymphocytes, macrophages, neutrophils) in tumours and an associate increase of cytokine (TNF- $\alpha=$ tumour necrosis factor $\alpha$, IL-1 $\alpha=$ interleukin-1 $\alpha$, IL-6 = interleukin-6, G-CSF = granulocyte colony stimulating factor) serum levels. They came to conclusion that the successful treatment with LPSp was mostly due to enhanced $\mathrm{T}$ cell-mediated antitumour immunity, supported by TNF- $\alpha$ and other cytokines. These results were confirmed by Inagawa et al. [30,31] who noted a complete regression of murine syngeneic tumours, Meth A fibrosarcoma, MH134 haepatoma and Lewis lung (LL) carcinoma after combined treatment with intradermally administered LPSp and cyclophosphamide. The authors underscored an important role of the TNF- $\alpha$ induction in successful therapy, and the low toxicity of the intradermally applied preparation which was 230-380 times smaller compared to intravenous administration.

The enhancement of the potentially anti-tumour cytokines by $P$. agglomerans LPS demonstrated by the Japanese researchers was confirmed by Dutkiewicz et al. [2, 32], who found in the rabbits inhaled with the microvesicular-bound LPS of P. agglomerans a significant growth of the levels of circulatory cytokines: total interferon (IFN), interleukin-1 $\alpha$ (IL-1 $\alpha)$, and tumour necrosis factor $\alpha$ (TNF- $\alpha)$. In another study, Spiewak and Dutkiewicz [33] stated that the microvesicular-bound LPS of $P$. agglomerans significantly stimulated the increase of interferon- $\gamma($ IFN- $\gamma)$ and TNF- $\alpha$ content in the culture of the human peripheral blood mononuclear cells.

Hino et al. [34] observed the induction of cell death in lung cancer cells when co-cultured with the rat alveolar macrophages or human monocytes that had been activated by the LPS preparations produced by Pantoea agglomerans 
or Escherichia coli. Despite the fact that both preparations exerted similar activation effects, the authors recommended the LPS of P. agglomerans for anticancer use because it has a lower molecular weight which enables easy absorption through the skin or mucosa. The LPS-activated rat alveolar macrophages produced large amounts of NO. According to the authors, this reaction was responsible, at least in part, for the lethal effect in cancer cells. In the case of activated human monocytes, the release of a cytotoxic agent was not noted.

More recently, Hebishima et al. [28] documented the usefulness of the IP-PA1 preparation as a supportive drug in melanoma therapy, reporting a significant prolongation of survival period in the melanoma-inoculated mice which were given IP-PA1 orally in combination with intraperitoneally given doxorubicin. The authors stated the increase of serum IFN- $\gamma$ level, as well as augmentation of the natural killer (NK) cells population, and of the ratio of CD4+ to CD8+ T cells in the spleen, which could be meaningful for final good results of the therapy. As IP-PA1 did not directly affect melanoma cells, the authors suggested that therapy success was related to the enhancement of mice immunity by IP-PA1, which neutralized the immunosuppressive action of doxorubicin.

Japanese researchers also successfully used the $P$. agglomerans LPS preparation for cancer treatment in humans. Kasugai et al. [24] applied the intradermal administration of LPSp in combination with transarterial intermittent chemotherapy (with 5-Fluorouracil, Farmorubicin, and Mitomycin C) for treatment of a patient suffering from advanced gastric cancer with multiple liver metastasis (H3). Therapy ended with full recovery: the computer tomography examination and endoscopy showed regression of the tumour and the patient was discharged from hospital. With the exception of fever, no serious side-effects were observed. The serum TNF- $\alpha$ levels were elevated and, as shown by histological examination, CD8+ lymphocytes dominantly infiltrated around the tumour. According to the authors, the achieved results clearly indicated the immunostimulative anti-tumour effect of LPSp, which appeared as a promising new adjuvant in cancer therapy. In a pilot clinical study, Goto et al. [35] applied intradermal administration of LPSp in combination with intravenous dosing of cyclophosphamide in the treatment of 10 patients with advanced cancer. Five of them had evaluable tumour, which had failed earlier to respond to conventional chemotherapy. After a 4-month therapy, a significant size reduction was noted in 3 of 5 evaluable tumours. Intradermally administered, LPS was well tolerated in high doses which contributed to the significant and continuous rise of cytokine (TNF- $\alpha$, IL-6, G-CSF) level. In conclusion, the authors recommended the use of $P$. agglomerans LPS for cancer treatment in humans.

Hebishima et al. [36] found the IP-PA1 preparation selectivity for normal and cancer cells. They demonstrated that IP-PA1 protects normal macrophages from cell growth inhibition induced by chemotherapeutic agent, but did not affect the cytotoxicity of the chemotherapeutic agents in carcinoma cells. According to the authors, the protective effect was mainly due to the activation of transcription factor $\mathrm{NF}-\kappa \mathrm{B}$ factor (nuclear factor- $\kappa \mathrm{B}$ ), an expression of antiapoptotic proteins and the production of NO and TNF- $\alpha$, the important mediators in the killing of tumour cells. The authors concluded that IP-PA1 can be used as an edible drug for the efficient support of chemotherapy.

\section{Other healing properties in humans and animals: a panacea?}

Broad spectrum of healing properties due to macrophage activation. Japanese researchers have demonstrated the extremely wide spectrum of healing properties revealed by the $P$. agglomerans LPS (IP-PA1), which is mainly due to its ability to activate macrophages that play an essential role in the maintenance of homeostasis in all multi-cellular animals [26]. By activation of macrophages, IP-PA1 assures homeostasis, protects multi-cellular organisms from external hazards, and contributes to recovery from a broad range of diseases, such as hyperlipidaemia, diabetes, ulcer, herpes and atopic allergy [26, 29]. It can also stimulate bone resorption and egg-laying, and exerts a strong analgesic effect that even allows a release from drug addiction [29]. Another advantageous property of IP-PA1 is its effectiveness when administered by the oral route which proved to be safe in large doses up to $600 \mathrm{mg} / \mathrm{kg}$, without any side-effects $[23,36$, $37,38,39,40]$. Kohchi et al. [26] and Inagawa et al. [40, 41] proposed that the mechanism for maintaining homeostasis by oral administration of $P$. agglomerans LPS includes a signal transfer system via cell-to-cell contact, termed the macrophage network system. According to these authors, oral application of IP-PA1 had preventive and curative properties against various diseases, including allergic and lifestyle-related diseases.

Hebishima et al. [39] demonstrated that IP-PA1 is a promising edible immunomodulator which could be used in the prevention and treatment of a wide range of disorders either caused or exacerbated by stress-induced immunosuppression in many animals and in humans.

According to Nakata et al. [42], the primary reason for the development of a stress-induced disease is suppression of macrophage function, which plays a pivotal role in innate immunity and maintenance of homeostasis. Hence, the activation of macrophages by priming with the P. agglomerans LPS (IP-PA1) prevents various kinds of stresses, such as chronic psychological stress, or surgery stress. Application of IP-PA1 prior to surgery by the oral route is both safe and useful for the prevention of infectious diseases and tumour metastasis.

Efficiency depending on structure. Inagawa et al. [38] examined the protective effect of various lipopolysaccharides prepared from 6 species of bacteria (Escherichia coli, Pantoea agglomerans, Serratia ficaria, Enterobacter cloacae, Bordetella pertussis, Alcaligenes faecalis), and from wheat flour on gastric ulcer in mice using parenteral as well as the oral route. LPS of Pantoea agglomerans appeared to be most effective among other examined LPSs. The biological activity of LPS depends on the chemical structure of its molecule composed of lipid A, core oligosaccharide and $\mathrm{O}$-antigen polysaccharide, and is determined mostly by lipid A moiety, although according to recent studies, $\mathrm{O}$-specific chains could be also important in this respect $[43,44,45]$. According to Kohchi et al. [26], the O-specific chain of P. agglomerans LPS (IP-PA1) is shorter compared to LPS of typical Escherichia coli and has a different composition. IPPA1 consists of rhamnose and glucose, whereas E. coli LPS consists of colitoses, glucosamine, glucose and galactose. The overall molecular weight of IP-PA1 is much smaller than E. coli LPS. Therefore, the small amphipathic IP-PA1 
easily forms a small-diameter micelle which easily penetrates through mucosa and/or skin, enhancing the positive effects of treatment after oral or intradermal administration [26]. This is noteworthy, that the safe and stable production process of IP-PA1, which is a water extract of $P$. agglomerans culture on a medium containing wheat flour, water and minerals $[26$, 41], reveals some similarities with the simple production process of the CA-S P. agglomerans preparation used by our group in numerous experiments [2]. The CA-S is obtained by the extraction of bacterial mass in saline and was found to exhibit strong immunostimulatory properties, including macrophage activation [2].

Anti-allergic effects of IP-PA1. Yoshida et al. [46] postulated that the anti-allergic effects of $P$. agglomerans LPS (IP-PA1) are due to shifting the Th1/Th2 balance towards Th1 response after activation of macrophages in the epidermis by LPS. As a result of this shift, the cytokines of Th1 type are produced instead of excessive reactions of Th2 type that cause allergic dermatitis or other IgE-dependent allergies. This view is in accordance with the studies performed in Germany and Switzerland which proved that allergic atopic diseases are less common among children raised on farms and exposed to early contacts with bacterial lipopolysaccharides (endotoxins) [47]. The anti-allergic action of $P$. agglomerans LPS has been confirmed recently by an experimental study by Wakame et al. [48], who demonstrated that the oral administration of IP-PA1 to NC/Nga mice exhibited inhibitory effects on atopic dermatitis symptoms induced by the topical application of the body extract of Dermatophagoides farinae, a known mite allergen associated with house dust (Fig. 1). The disease process alleviation has been evidenced by the significantly decreased severity of inflammatory skin lesions and lowered serum levels of the allergic type I disease markers: IgE, periostin, and TARC (thymus and activationregulated chemokine), indicating a Th2 to Th1 shift. The authors expressed an opinion that IP-PA1 could be effective for the prevention of atopic dermatitis and inhibition of its exacerbation. Thus, the same $P$. agglomerans species which causes occupational, non-atopic allergic diseases in workers exposed to organic dusts [2], may be very efficient in the treatment of atopic, IgE-mediated allergic diseases.
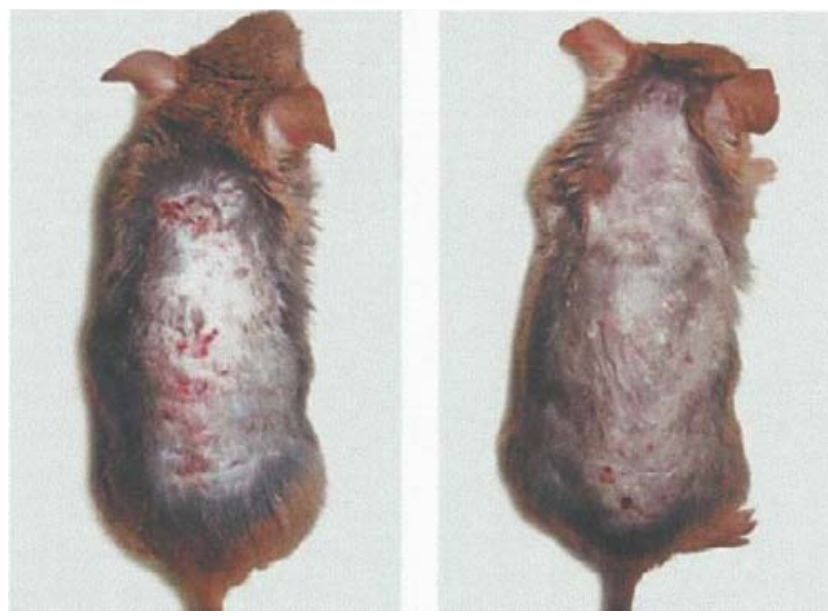

Figure 1. Dorsal skin of mice topically exposed to the extract of Dermatophagoides farinae with no treatment (left) and oral treatment with P. agglomerans LPS (IP-PA1) (right). The non-treated mice developed atopic dermatitis symptoms (erythema, haemorrhages) which were remarkably reduced by the treatment with IP-PA1. According to Wakame et al. [48], with permission
Analgesic and psychotropic effects. IP-PA1 showed also an analgesic effect in mice, rats and humans [40,49]. Kamei et al. [50] demonstrated that subcutaneous injection of the $P$. agglomerans LPS (LPSp) suppressed hyperalgesia in streptozotocin-induced diabetic mice, and concluded that LPSp may be effective in relieving the pain associated with diabetic neuropathy. Okutomi et al. [51] and Okutomi and Suzuki [52] reported that LPSp showed a relief effect on the physical dependence of morphine and psychic dependence of cocaine by induction of endogenous opioid, beta-endorphin. The LPSp was more effective than LPS from E. coli or Bordetella pertussis, and thus was considered to be applicable for clinical use [51]. These results were confirmed by Suzuki et al. [53], who found that LPSp blocks both the reinforcing and the locomotor enhancing effects of cocaine, and therefore might be useful in pharmacotherapy for the prevention of recurrent cocaine abuse.

Prevention and treatment of infectious diseases in humans and animals. Besides the antibiotics produced by $P$. agglomerans, which were characterized in one of the preceding chapters of this article, the bacterium may be efficient in the prevention and treatment of various infectious diseases of humans and animals by other mechanisms, including the protective action of the lipopolysaccharide preparation from $P$. agglomerans (LPSp, IP-PA1) isolated by the Japanese scientists $[26,41]$. The protective action is mainly due to the increase of innate immunity by macrophage activation.

Very significant results were recently obtained by Fukasaka et al. [54], who demonstrated that the LPS preparation from $P$. agglomerans (denoted by the authors as LPSpa) caused a strong immune response in mice when given sublingually together with influenza vaccine. LPSpa proved to be a potent adjuvant that induced both systemic (IgG-mediated) and mucosal (IgA-mediated) antibody responses by activating innate immune cells (macrophages and dendritic cells) via a Toll-like receptor 4 (TLR4). This was followed by cytokine production, migration of dendritic cells to cervical lymph nodes and presentation of antigen to $\mathrm{T}$ cells, leading to the activation of the adaptive (acquired) immune system. It is noteworthy that LPSpa induced a stronger cytokine response than MPL (Monophosphoryl lipid A), one of the few adjuvants commonly used in human vaccination. The potent immune response resulted in a significant increase in the mice survival rate against lethal influenza virus challenge, compared with subcutaneous vaccination. The authors concluded that sublingual vaccination with LPSpa (as TLR4 ligand) associated with the specific viral antigen might be an ideal vaccination strategy against the influenza virus, and probably also against other viruses.

Feeding animals with food containing IP-PA1 protects them against infection by increasing innate immunity and limits the overuse of antibiotics. Komori et al. [55] have recently shown that oral administration of IP-PA1 to broiler chickens significantly reduced their mortality, induced cytokine expression, and stimulated phagocytic activity and nitric oxide (NO) production by peripheral blood monocytes. According to the authors, all these effects were due to priming of macrophage activation as a result of the innate immunity enhancement by P. agglomerans LPS. Hebishima et al. [56] demonstrated that oral pretreatment of chickens with IPPA1 inhibited the stress-induced immunosuppression, 
caused by intramuscular administration of dexamethasone, a synthetic stress-eliciting glucocorticoid. The P. agglomerans immunopotentiator protected the birds against weight loss, excessive apoptosis of lymphocytes and decrease of antibody response to Salmonella enteritidis vaccine and sheep erythrocytes. The authors concluded that IP-PA1 could be useful in controlling immunosuppression in poultry husbandry, which may be caused by overcrowding stress, and could result in an enhanced risk of food-borne salmonellosis. Kohchi et al. [26] reported that mortality among chickens fed with food containing IP-PA1 was significantly lower compared to those which received Calspollin, or Calsporin (a probiotic produced in Japan containing viable spores of Bacillus subtilis).

In other studies, Japanese researchers demonstrated in experiments on aquatic animals that feeding with IP-PA1 protected kuruma shrimp (Penaeus japonicus) against penaeid acute viraemia (white spot virus), ayu fish (Plecoglossus altivelis) against Pseudomonas and Flavobacterium infections, and carp (Cyprinus carpio) against koi herpesvirus [26, 41, 57]. Kadowaki et al. [58] demonstrated that oral administration of IP-PA1 to carp induced activation of M1 type macrophages which are responsible for antibacterial and anti-tumour defence, and caused the significant enhancement of the bactericidal activity of the head kidney leukocytes against a fish pathogen Aeromonas hydrophila. Carbajal-González et al. [59] report that P. agglomerans occurring in trout as a natural constituent of microbiome, protects the fish against Saprolegnia parasitica, the oomycete fungus-like protist which evokes saprolegniosis, a severe disease in trout.

Suzuki et al. [60] demonstrated that an oral administration of a small amount of the lipopolysaccharide from wheat flour (LPSw), equal to $P$. agglomerans LPS (LPSp), significantly decreased mouse mortality and prevented animal weight loss in acute infection with Toxoplasma gondii, a deadly sporozoan parasite. A similar effect was achieved by the administration of LPS from Bordetella pertussis, whereas LPS from Escherichia coli and synthetic lipid A did not show a significant decrease in mortality. Wang et al. [61] proved that LPSp can act as the adjuvant of the hepatitis B virus (HBV) antigen, and effectively increased the production of anti-HBV antibodies in the mice immunized by the HBV antigen.

Mushtaq et al. [62] have recently demonstrated that Pantoea could be included in probiotics, as a Pantoea sp. strain isolated from human gut was found to produce colicin that inhibited the growth of Escherichia coli O157:H7, which is a known enteric pathogen. The P. agglomerans endophytic strains isolated by Rafat et al. [63] from Centella asiatica, an important Asian medicinal plant, inhibited the growth of the pathogenic bacterium Pseudomonas aeruginosa, but did not affect the growth of Escherichia coli, Staphylococcus aureus and Bacillus cereus.

Other healing properties. Okutomi et al. [64] found in experiments on rabbits that the serum levels of cholesterol and apolipoprotein B (a constituent of low-density lipoprotein, described as LDL or 'bad' cholesterol) decreased with uptake of IP-PA1 contained in water. Conversely, the level of high-density lipoprotein (described as HDL or 'good' cholesterol) did not change. Iguchi et al. [65] showed that the intradermal administration of IP-PA1 had a suppressive effect on diabetes progression in mice. More recently, Nakata et al. [66] demonstrated that a combination of soy milk and
P. agglomerans LPS (LPSp) given orally to premenopausal women may be useful for osteoporosis prevention.

Apart from curative effects, IP-PA1 could be efficiently used for various preventive purposes, e.g. as a constituent of skin-care cosmetics and health foods to prevent and improve metabolic syndromes $[26,41]$. It was also proved that IP-PA1 applied as an additive to human skincare cream was effective for moisture retention and curing of burns, pressure sores and atopic dermatitis [26]. Suzuki et al. [67] evidenced the enhancement effect of IP-PA1 on hen egg-laying and the breaking strength of eggshells.

Pantoea agglomerans was among 9 bacterial species which have been recently isolated by Nicoletti et al. [68] from spring water samples collected in Comano, Italy. The Italian researchers hypothesize that these bacterial isolates may contribute to the regenerative and wound healing properties of Comano spring water [68].

\section{Fighting of diseases transmitted by arthropod vectors and arthropod pests with use of paratrangenesis}

Common occurrence in arthropods. Pantoea agglomerans strains are widespread, usually as symbionts, among arthropods which form the largest phylum in the animal kingdom. As indicated in the preceding article [3], they occur mostly in insects, but were isolated also from species belonging to other arthropod taxa. This article also reviewed examples of insects exerting deleterious effects as vectors of plant diseases $[69,70]$.

Combating malaria using paratransgenesis strategy. In the light of the recent publications, combating malaria appears to be the most promising field for the efficient use of engineered P. agglomerans strains. Pantoea was identified as the most prevalent symbiotic bacterium living in the midgut of anopheline mosquitoes [71, 72, 73] which transmit Plasmodium protozoans causing malaria, one of the most lethal infectious diseases in the world, with about 300-500 million cases and 1.2 million deaths annually [73]. The common occurrence of Pantoea symbionts in malaria vectors allows for the development of a strategy termed paratransgenesis in which the symbiont is engineered to express and secrete anti-Plasmodium effector proteins in mosquito mid-gut. The final step in the strategy is to introduce these transgenic symbionts into the vector populations in the wild [72, 73]. The use of this strategy by Wang et al. [73] appeared successful: the engineered $P$. agglomerans strains inhibited development of the human malaria parasite Plasmodium falciparum and rodent malaria parasite Plasmodium berghei by up to $98 \%$, which creates new prospects for combating the deadly disease.

Combating other diseases or pests with the use of paratransgenesis. Pantoea agglomerans also occurs commonly in the gut of sand flies Lutzomyia longipalpis and Phlebotomus papatasi which are vectors of leishmaniasis, a disease caused by the protozoan parasites belonging to Leishmania genus $[74,75]$. Paratransgenesis with the use of P. agglomerans is therefore also considered in the case of this vector-borne disease.

The common occurrence of $P$. agglomerans as symbionts inside arthropods or inside plants affected by arthropod 
pests, also creates promising possibilities for combating arthropod pests or pathogens transmitted by arthropod vectors with the use of paratransgenesis, as genetically modified symbiotic strains of Pantoea have a much greater chance to develop inside arthropods than the exogenous strains of bacteria routinely used to kill the pest. Thus, Quecine et al. [76] recently demonstrated that an endophytic P. agglomerans 33.1 strain, identified earlier as a promising sugarcane growth promoter and living in the same niche as the larvae of the sugarcane borer Diatraea saccharalis (Lepidoptera: Pyralidae), proved to be efficient as a biocontrol agent of this insect pest after genetic modification causing expressing of the insecticide Cry protein. Paratransgenesis appears also as a promising strategy in the control of such insect pests as locusts (Schistocerca gregaria) [77] or blueberry maggot fly (Rhagoletis mendax) [78] in which P. agglomerans commonly exists in the gut as a symbiont.

A field application of paratransgenesis requests a safe delivery of transformed microbes into the natural environment, addressing appropriate regulations. Major progress in this area has been recently achieved by Arora et al. [79], who successfully used a biopolymer (calcium-alginate) microencapsulation system for the containment and safe introduction of genetically engineered $P$. agglomerans E325 strain to the gut of glassy-winged sharpshooter (Homalodisca vitripennis), a leafhopper pest transmitting the plant pathogenic bacteria Xylella fastidiosa. This strategy decreases the risk of environmental contamination, horizontal gene transfer, and competition with native species by acting as a barrier between recombinant bacteria and the environment, thereby opening a real perspective for the application of paratransgenesis with the use of $P$. agglomerans for control of vector-borne diseases such as malaria and leishmaniasis.

\section{An effective weapon against pathogens and pests of cultivable plants}

Combating bacterial pathogens. Pantoea agglomerans has been identified as an antagonist of many plant pathogens belonging to bacteria and fungi, which is associated with the production of antibiotics or other mechanisms. This enables its use as a biocontrol, and being a healthy and environmental-friendly procedure, permits the decrease in pesticide doses, or even avoid the use of chemicals [80]. Best known is its use with commercially available strains E325, P10c, C9-1 (the latter recently classified as Pantoea vagans) for control of the bacterial plant pathogen Erwinia amylovora that causes fire blight, a devastating disease of apples and pears $[18,81]$. The effectiveness of $P$. agglomerans in treatment of this disease is primarily due to the abovementioned production of antibiotics $[13,14,15,18,81]$, some of which could target amino acid biosynthesis in the pathogen [10], and secondly to the competition in which P. agglomerans is more successful than the pathogen in colonizing flower stigmas of apple and pear trees [81].

Pantoea agglomerans is also effective in the protection of vegetables. Strains of this bacterium isolated from potato tubers in Canada were found to inhibit the growth of Peptobacterium atrosepticum, the causative agent of potato blackleg [82]. Hsieh et al. [83] proved that seed treatment with P. agglomerans may be an effective and practical method for the control of bean wilt caused by Curtobacterium flaccumfaciens pv. flaccumfaciens. Sadik et al. [84] reported that the P. agglomerans 2066-7 strain was the most effective biocontrol agent against onion bacterial diseases caused by Pseudomonas marginalis, Pantoea ananatis, Pseudomonas viridiflava and Xanthomonas retroflexus in Morocco.

$P$. agglomerans is also efficient for reduction of bacterial diseases of monocotyledon crops, such as a serious blight caused by Xanthomonas oryzae pv. oryzae in rice [85]. Braun-Kiewnick et al. [86] demonstrated that strains of $P$. agglomerans suppressed the development of basal kernel blight of barley caused by Pseudomonas syringae pv. syringae, when applied to heads prior to pathogen. On the other hand, Pasichnyk et al. [87] showed that P. agglomerans competes effectively with Pseudomonas syringae pv. atrofaciens, the agent of basal bacteriosis of wheat, by quicker propagation and inhibition of the pathogen's growth.

Besides antibiosis and competition, the other mechanisms of the antagonistic properties of $P$. agglomerans are less well known and are often related to the induction of plant resistance. Han et al. [88] showed that P. agglomerans was effective in inducing systemic resistance in radish to bacterial leaf spot caused by Xanthomonas campestris pv. armoraciae. Ortmann and Moerschbacher [89] and Ortmann et al. [90] demonstrated that exopolysaccharides of this bacterium induce the disease resistance of monocotyledon plant species, such as wheat and rice, by priming their cells for potentiation of the defence response elicited by contact with the pathogen (or a corresponding substance) which could manifest by the generation of $\mathrm{H}_{2} \mathrm{O}_{2}$ defined as an 'oxidative burst'.

Combating fungal pathogens. Pantoea agglomerans has also shown an inhibitory activity against a number of important fungal plant pathogens, including: • Fusarium culmorum, a soil-borne fungal pathogen that causes seedling and head blight, and foot and root rot of wheat, and Puccinia recondita f. sp. tritici causing brown rust of wheat [11]; • phytopathogenic and mycotoxin-producing strains Fusarium avenaceum, F. oxysporum, and F. gibbosum (teleomorph: Gibberella intricans) [91]; - Fusarium graminearum [teleomorph: Gibberella zeae] reported as a cause of Fusarium head blight or scab, responsible for major yield and grain quality losses in wheat, maize, barley, and oats - known also as a myxotoxin producer (Fig. 2) [92]; • Gibberella pulicaris (anamorph: Fusarium sambucinum), an ascomycete causing dry rot of potatoes [93]; • Magnaporthe grisea (anamorph: Pyricularia grisea), a rice blast fungus causing a serious disease of rice, and Cladosporium cucumerinum, a fungal pathogen causing scab of cucurbits, a disease of cucumber, cantaloupe, honeydew, summer and winter squash, pumpkin, and gourds [94]; • Rhizoctonia solani (teleomorph: Thanatephorus spp.),
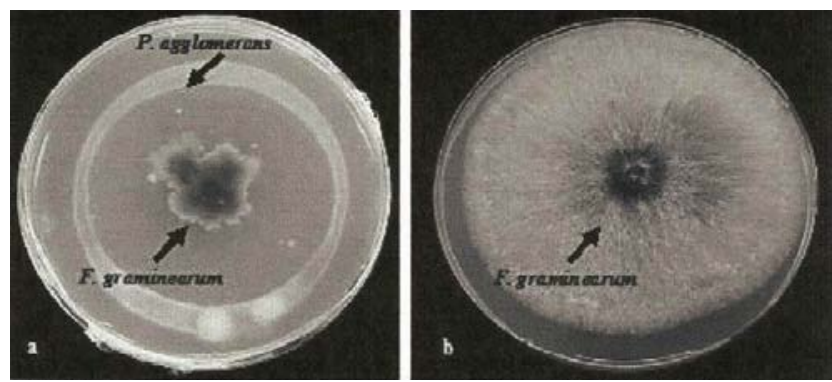

Figure 2. Pantoea agglomerans inhibited the growth of Fusarium graminearum (left) while on the medium containing only F. graminearum (right) the abundant growth of the fungus is seen. According to Pandolfi et al. [92], with permission 
a plant pathogenic fungus with a wide host range [95]; • Exserohilum turcicum (synonym: Helminthosporium turcicum) causing the northern leaf blight of maize [96]; - Macrophomina phaseolina, a causal agent of charcoal rot of soybean [97]; • Colletotrichum musae and Lasiodiplodia (Botryodiplodia) theobromae, fungal pathogens causing crown rot of bananas [98]. Three P. agglomerans strains isolated from the rhizosphere of grape bushes in Uzbekistan showed a strong anti-fungal activity due to production of chitinolytic enzymes [99]. The stimulation of plant resistance was also considered as a mechanism that protects against fungal pathogens. Verhagen et al. [100] demonstrated that $P$. agglomerans was capable of inducing oxidative burst and phytoalexin production in grapevine, leading to differential local and systemic resistance to a fungal pathogen Botrytis cinerea causing grey mould disease. Similarly, Zhang et al. [101] evidenced that an application of Pantoea agglomerans to cucumbers significantly reduced, by inducing systemic acquired resistance, the severity of anthracnose, a disease caused by a pathogenic fungus Colletotrichum orbiculare. Vanneste et al. [102] showed that Pantoea agglomerans enhanced the resistance in kiwi fruit and tobacco, thus protecting these plants from a disease called white mould, caused by an ascomycete, Sclerotinia sclerotiorum.

Very good results were obtained by the use of $P$. agglomerans for the protection of stored fruits against fungal pathogens. It has been shown that the Pantoea agglomerans CPA-1 and CPA-2 strains provided excellent control against fungi of the species Botrytis cinerea, Penicillium expansum that Rhizopus stolonifer, causing post-harvest diseases of pome fruits (pear and apple), and inhibited the accumulation of patulin, a mycotoxin produced by $P$. expansum that affects human health $[80,103,104]$. The CPA-2 strain also significantly reduced the incidence of Penicillium digitatum (green mould) and Penicillium italicum (blue mould) on stored citrus fruits (oranges, mandarins and lemons) $[105,106]$. P. agglomerans strain EPS125 also efficiently protected stone fruits (apricot, peach and nectarine) against brown rot caused by Monilinia laxa and soft rot caused by Rhizopus stolonifer [107], while 4 $P$. agglomerans strains isolated from pome fruits in Turkey efficiently inhibited the growth of Aspergillus flavus on stored lemons [108]. Zhang et al. [109] recently reported that the $P$. agglomerans XM2 strain isolated from prunes in China was effective in post-harvest control of black spot disease caused by the fungus Alternaria alternata on pears.

Combating other pathogens and pests. Bardin et al. [110] reported the Pantoea agglomerans 2-2 strain as one of 6 bacterial strains which proved to be effective seed-treatment agents for the control of damping-off of canola, safflower, dry pea, and sugar beet in fields naturally infested by Pythium sp. (an oomycete protist with fungal-like features), a causative agent of the disease. Munif et al. [111] reported that the P. agglomerans MK-29 strain was among 4 strains of endophytic Gram-negative bacteria isolated from tomato which significantly reduced the infestation of root-knot nematode Meloidogyne incognita on tomato when applied as a seed treatment, root dipping, or as a soil drench. This suggests a potential for the efficient use of bacterial biocontrol agents instead of anti-nematode pesticides which exhibit high toxicity and negative impact on the environment.

Pantoea agglomerans has also been shown to be pathogenic to couch grass (Elytrigia (=Elymus) repens), which creates the possibility to use it as biocontrol agent against this widespread plant pest [112].

\section{Growth promotion of cultivable plants}

Growth promotion by $\boldsymbol{P}$. agglomerans strains associated with rhizosphere. Pantoea agglomerans strains occurring in rhizosphere (root-soil interface) of cultivable plants may promote the growth of these plants by various mechanisms. Son et al. in Korea [113], Malboobi et al. in Iran [114, 115] and Sulbarán et al. in Venezuela [116] demonstrated that $P$. agglomerans strains isolated from soil exerted a beneficial effect for crops by solubilization of otherwise insoluble inorganic phosphates. Malboobi et al. [114, 115] demonstrated in both the greenhouse and in field trials that $P$. agglomerans was very efficient in the promotion of potato growth, mostly if applied in combination with the other phosphate-solubilizing strains belonging to the species Microbacterium laevaniformans and Pseudomonas putida. The authors expressed an opinion that these isolates are superior candidates for biofertilizers. Lakshmanan et al. [117] proved that Pantoea sp. strain EA106, a natural rice rhizospheric isolate, abates arsenic uptake in rice by a high siderophore (iron binding) activity, resulting in increasing Fe plaque formation on rice roots. This promotes the rice growth and prevents accumulation of toxic arsenic in the plant tissues. Khalimi et al. [118] demonstrated that treatment of rice seeds with the bacterial suspension of 2 P. agglomerans strains isolated from rhizosphere of a groundnut, significantly increased the plant growth and yield of rice in Bali, Indonesia. Amellal et al. [119] observed that the P. agglomerans NAS206 strain isolated from the rhizosphere of wheat in Morocco secreted an exopolysaccharide which had a positive effect on rhizosphere soil aggregation and plant growth. Two strains exhibiting potent useful properties have been isolated from rhizosphere in India: the P. agglomerans NBRISRM strain that enhanced the macronutrient uptake by maize and chickpea and promoted the growth of these plants [120], and the Pantoea sp. NII-186 strain, which showed multiple plant growth-promoting attributes, such as phosphate solubilization activity, as well as indole acetic acid (IAA), siderophore, and HCN production [121]. Additionally, the latter strain showed significant growth inhibitory activity against phytopathogenic fungi, and extremely wide tolerance to different environmental conditions, such as temperature, salt concentration and $\mathrm{pH}$ range, which makes it an ideal candidate for a bioinoculant replacing chemical fertilizers [121]. Similar properties to the NII-186 strain revealed the plant-growth-promoting P. agglomerans diazotrophic ( $\mathrm{N}_{2}$-fixing) lma2 strain, isolated from the wheat rhizosphere of an arid region in Algeria, recommended it as a potentially good fertilizer in arid and saline zone [122]. Earlier, the $P$. agglomerans diazotrophic strains detected in the rhizosphere of wheat and barley in Germany had been indicated as potential bio-fertilizers [123].

Pantoea agglomerans and closely related Pantoea species produce phytase, an enzyme degrading phytate [124, 125, $126,127]$. Phytate, the salt form of a saturated cyclic acid called phytic acid, occurs commonly in plants and soil, making up to $90 \%$ of the natural phosphorus in the world [126]. However, only ruminant animals decompose phytate, whereas other animals and plants do not. Thus, phytase 
enzymes produced by $P$. agglomerans and other bacterial species occurring in rhizosphere and other soil layers are crucial for making this rich phosphorus source available to plants and the majority of animals. In this context, the studies by Suleimanova et al. $[126,127]$ are very significant. They isolated from a sample of forest soil collected in the Republic of Tatarstan, Russia, a Pantoea sp. 3.5.1. strain exhibiting a very high activity of phytase encoded by the agpP gene [127]. The strain is closely related to $P$. agglomerans but probably represents a new species [126]. The authors sequenced the full genome of this strain [126] and proposed its potential use as an environmentally friendly biofertilizer, as a feed supplement for livestock production, or as a raw material for the industrial production of microbial phytase, which by now is mostly produced from the Aspergillus strains [127].

Growth promotion by the endophytic $P$. agglomerans strains. The endophytic P. agglomerans strains developing inside plant tissues may promote plant growth mainly by the atmospheric nitrogen $\left(\mathrm{N}_{2}\right)$ fixation ability, production of phytohormones, and disease control [128]. Scholz-Seidel and Ruppel [129] demonstrated that the P. agglomerans strain isolated from phyllosphere (air-surface interface of plant leaves) of wheat in Germany showed the presence of nitrogenase ( $\mathrm{N}_{2}$-fixing enzyme) and phytohormone activities that promote plant growth and increase the root length and yield of winter wheat. Inoculation experiments with diazotrophic $P$. agglomerans strains on wheat and barley in temperate regions have demonstrated the possibility of increasing yield up to $500 \mathrm{~kg} / \mathrm{ha}$ [130]. A growth-promoting effect of inoculation with $P$. agglomerans on wheat was confirmed by Remus et al. [131], who evidenced that inoculating seeds and shoots with this bacterium increased the yield of wheat grain up to $23.5 \%$, and by Egamberdiyeva and Höflich [132], who noted the growth promotion of winter wheat.

Verma et al. [133] demonstrated that $P$. agglomerans strains isolated from deepwater rice in India appear to be very competent plant growth-promoting endophytes, which are equipped with the ability to fix atmospheric nitrogen, produce indole acetic acid (IAA) and mineralize insoluble phosphates. They produce pectinases and cellulases enabling penetration and spread inside rice and providing biologically fixed nitrogen to the distant parts of plant. Similarly, Feng et al. [128] evidenced that the P. agglomerans YS19 diazotrophic strain identified in China as rice endophyte, produced phytohormones, enhanced transportation of the photosynthetic assimilation products and promoted host plant growth showing a potential for increasing rice production in field application. Miao et al. [134] demonstrated a strong adsorption of the $P$. agglomerans YS19 cells by rice root hairs indicating a close interrelation between $P$. agglomerans and host plant. Further studies on the properties of the YS19 strain showed the presence of the defined in preceding article [3, 7] quorum sensing (QS) system. In this case, $Q S$ was proved to regulate, by means of acyl-homoserine lactone (AHL) diffusible signal molecule (identified as N-3-oxooctanoylL-homoserine lactone (OOHL)), such life functions of bacteria as forming of cell aggregates, called symplasmata, and interrelations between bacterium and host, including the colonization of plant tissues and promotion of rice growth [9]. The potential beneficial effects of $P$. agglomerans on rice growth has been confirmed recently by Banik et al.
[135], who identified the presence of 2 Pantoea spp. strains among 11 diazotrophic bacterial isolates from rice plants in India, which possessed the nifH (nitrogen fixation) gene and promoted the growth of rice seedlings. All these findings are very significant because rice is the staple food of $50 \%$ of world's population and $80 \%$ the population of Asia [135].

A similar Pantoea sp. 9C diazotrophic strain with an extremely high nitrogenase activity was identified in Cuba as an endophyte of sugarcane [136]. Similar to an Indian NII-186 strain [121], the sugarcane strain revealed an exceptionally wide tolerance to environmental conditions and has been proposed as a candidate for an environmentfriendly biofertilizer [136]. Gond et al. [137] recently demonstrated that $P$. agglomerans isolated from teosinte (an ancestor of corn) induces salt tolerance in tropical corn, which creates the chance to increase its cultivation area and yield on saline soils (Fig. 3). Quecine et al. [138] showed that the $P$. agglomerans endophytic 33.1 strain, originally isolated from Eucalyptus grandis, was able to cross-colonize and promote the growth of sugarcane. It also induced the synthesis of chitinase and endoglucanase enzymes, which are associated with plant protection against pathogens. These results suggest that this strain could be used as an inoculant to improve sugarcane productivity. Andreote et al. [139], Ferreira et al. [140] and De Lima Procopio et al. [141], have proposed using the endophytic, plasmid-harbouring P. agglomerans strains abundantly colonizing seedlings of citrus plants and eucalyptuses, as vehicles for the introduction of exogenous genes promoting growth of these cultivars.

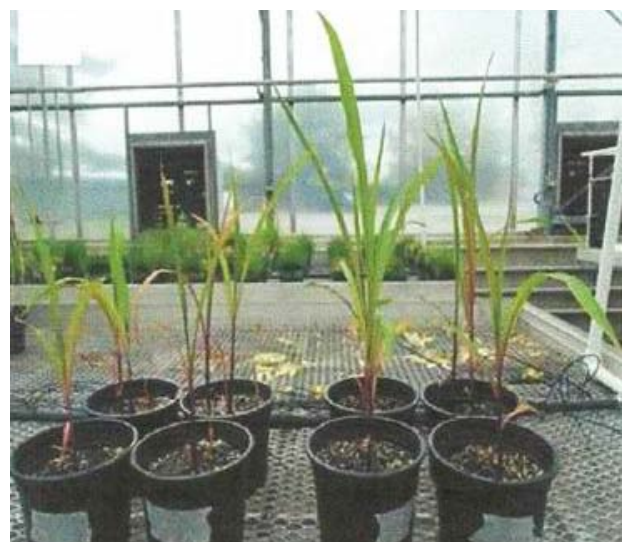

Figure 3. Induction of salt tolerance by Pantoea agglomerans. The tropical corn seedlings treated with $P$. agglomerans suspension and grown in saline soil in a greenhouse (right) showed a significant growth enhancement compared to untreated plants (left). According to Gond et al. [137], with permission

Asis and Adachi [142] isolated from the stem of sweet potato in Japan, a diazotrophic P. agglomerans strain, with a potential to increase nitrogen uptake by this important Japanese crop plant. Jasim et al. [143] have recently demonstrated that the strain determined as Pantoea sp., isolated from the cardamom (Elettaria cardamomum) fruit tissue in India, showed the ability to produce ACC (1-aminocyclopropane-1carboxylate) deaminase which regulates the ethylene level in plant tissues and thereby promotes plant growth. De Almeida Lopes et al. [144] have evidenced that Pantoea agglomerans and Variovorax paradoxus strains showed the highest efficiency in IAA production and phosphate solubilization among all bacterial endophytic strains isolated from soybean 
in Brazil, thus revealing the potential to promote the growth of this important cultivable plant. Dursun et al. [145] stated that a foliar spray with a suspension of $P$. agglomerans FF strain significantly increased the yield, growth and mineral contents of tomato and cucumber fruits in Turkey.

\section{Efficient bioremediation}

Strong biodegradation activity. Recent reports indicate that the bacteria of the Pantoea genus reveal a great potential for bioremediation, e.g. a waste management technique that involves the use of organisms to remove or neutralize chemical pollutants from the natural environment. It has been documented that the Pantoea strains show biodegradation activity on various substrates with aromatic rings, such as phenol [146], alkylbenzosulfonate and sodium dodecyl sulphate surfactants [147], 2,4,6-trinitrotoluene [148], tannic acid [149], and the herbicide mesotrione [150, 151]. Jacobucci et al. [152] found that a biosurfactant produced by $P$. agglomerans was efficient in the bioremediation of the oily effluent released by the margarine and soap industry, as shown by the reduction of the COD (Chemical Oxygen Demand) index by $70 \%$.

Biodegradation of rice straw. The most interesting approach to this issue has been presented by Xiong et al. [151], who found that the rice endophytic strain Pantoea sp. Sd-1, closely related to $P$. agglomerans, showed an exceptional ability to degrade rice straw and lignin (Fig. 4). This creates an
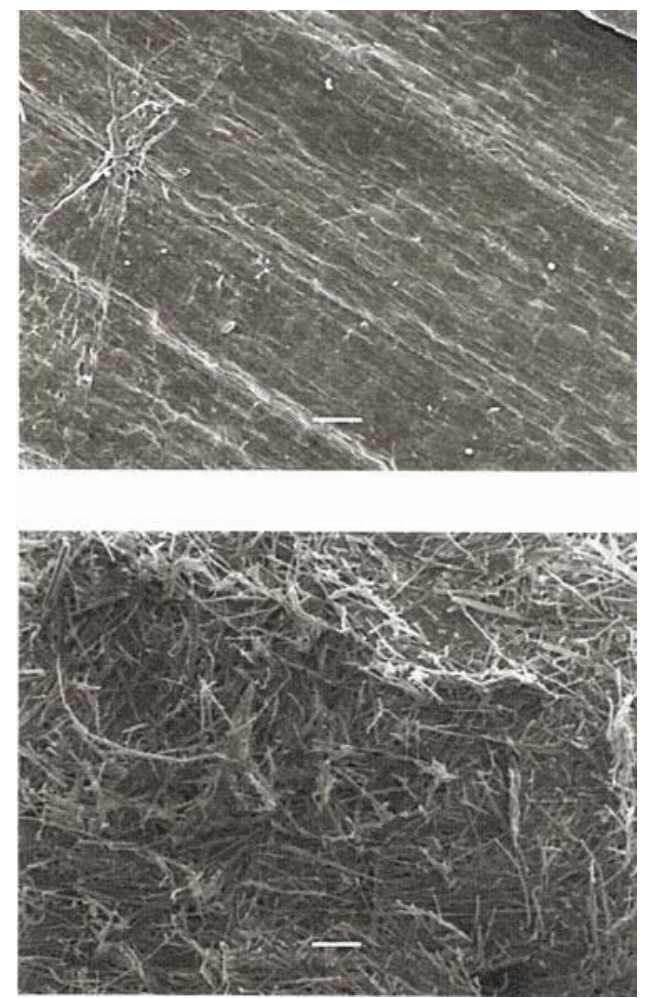

Figure 4. Degradation of rice straw with P. agglomerans strain $\mathrm{Sd}-1$, causing changes in its surface morphology recorded by scanning electron microscopy (SEM). The untreated rice straw (upper photo) has a smooth surface and its fragments closely connected, while the surface structure of rice straw treated with P.agglomerans (lower photo) is rough, and the fragments broken into very loose, small pieces. According to Xiong et al. [151], with permission encouraging perspective for utilizing rice straw that could be used in industry for the production of bioethanol and paper, or as a renewable energy source. At present, however, the durability of lignin is the major obstacle to the utilization of rice straw and the reason for large-scale deposition of this abundant agricultural by-product which poses a considerable threat to the natural environment. The application of Pantoea for biodegradation of rice straw and other materials containing lignocellulose biomass may efficiently solve this important problem.

Degradation of hydrocarbons. Pantoea has also been identified as a member of microbial communities used for the biological degradation of polycyclic aromatic hydrocarbons, produced from the incomplete combustion of organic materials and fossil fuels in various industrial activities, and regarded as environmental pollutants of particular concern [153]. Vasileva-Tonkova and Gesheva [154] found that the Pantoea sp. A-13 strain isolated from soil in Antarctica produced a potent glycolipid biosurfactant which could be used for the degradation of petroleum hydrocarbons and environmental bioremediation. The research performed by a group of scientists from Pakistan and Austria has documented the outstanding potential of Pantoea agglomerans strains for the degradation of petroleum hydrocarbons in spilled soil $[155,156,157,158]$. Yousaf et al. [155] proved a very high efficiency of hydrocarbon degradation by the P. agglomerans BTRH79 and ITSI10 plant isolates in combination with plants: Italian ryegrass (Lolium multiflorum var. Taurus) and bird's-foot trefoil (Lotus corniculatus var. Leo). The high performance of the P. agglomerans BTRH79 strain in hydrocarbon removal was related to the presence of alkane hydroxylase CYP153 gene with a substrate range between $\mathrm{C}_{4}-\mathrm{C}_{16}[155]$. Further studies by the Pakistani-Austrian group $[156,157,158]$ confirmed this performance, either for the BTRH79 strain alone or in combination with the other P. agglomerans, Pseudomonas sp., and Burkholderia sp. inoculant strains. Based on these studies, the group proposed an efficient phytoremediation system for the reduction of hydrocarbon contamination in which the inoculation of soil with pollutant-degrading bacteria was combined with the planting of proper vegetation, and amendment of soil with nutrients, such as compost or fertilizers containing nitrogen, phosphorus and potassium. In this system of a plant-bacterium partnership, inoculated bacteria promote plant growth by both detoxification of the environment and the ACC deaminase activity, receiving in turn habitat and nutrients [157]. P. agglomerans is also an important member of the microbiota found in most biological degreasing systems used for degradation and removal of oil, grease, or lubricants from the metal parts of machines or installations, as an environment-friendly alternative to hazardous chemical solvents [159].

Reduction of toxic metals and metalloids. The facultative anaerobic Pantoea agglomerans strains show a potential to detoxify the environment through the oxidation of acetate or $\mathrm{H}_{2}$ to dissimilatory reduction of metals, such as $\mathrm{Fe}(\mathrm{III}), \mathrm{Mn}^{2}(\mathrm{IV})$ and the highly toxic $\mathrm{Cr}(\mathrm{VI})[160,161]$. These results correspond with a study performed by Ozdemir et al. [162], who demonstrated that the Pantoea sp. TEM18 copper tolerant strain, isolated from activated sludge of a petrochemical industry wastewater treatment plant, showed 
a high adsorption capacity for heavy metal ions $\mathrm{Cr}(\mathrm{VI})$, $\mathrm{Cd}(\mathrm{II})$ and $\mathrm{Cu}(\mathrm{II})$, creating a promising perspective for the effective treatment of wastewater polluted with toxic metals. P. agglomerans was also among 7 strains which were proved by Zaets et al. [163] to be effective in the protection of soybean plants against accumulation of toxic cadmium present in soil. Similarly, Pishchik et al. [164] demonstrated that inoculation of $P$. agglomerans into soil highly contaminated with toxic cadmium and lead resulted in a decrease of their content by 2-3 times and 4-5 times, respectively, and furthermore, caused a significant increase of the oats yield which exceeded even the yield noted in soils not contaminated with heavy metals. According to Tian et al. [165], the Pantoea sp. IMH strain carrying the ars $\mathrm{C}$ gene and highly resistant to heavy metals, was effective in the aerobic reduction of $\operatorname{arsenic}(\mathrm{V})$ present in the solid waste released by a copper-smelting plant.

Prevention of penetration of toxic contaminants into soil. Besides significant chemical effects, Pantoea agglomerans may prevent penetration of harmful industrial contaminants into deeper parts of soil on a physicochemical basis. KurlandaWitek et al. [166] have experimentally demonstrated that even a thin layer of a biofilm formed by $P$. agglomerans can hinder the migration of zinc oxide nanoparticles downwards porous media. The authors postulated that such biofilms could be used as a potential remediation strategy against the migration of nanoparticle contaminants in heterogeneous aquifers [166].

Waste recycling associated with energy acquisition. The strains of $P$. agglomerans could also be useful in the acquisition of energy from various alternative sources, such as waste recycling. An example is the salt-tolerant P. agglomerans BH-18 strain isolated by Zhu et al. [167] from mangrove sludge, which possesses the ability to produce hydrogen. The authors proposed using this strain for the biological treatment of marine aquaculture wastewater and marine organic waste, associated with the production of biohydrogen that represents a promising alternative source of energy due to its reproducibility, non-polluting nature, and high energy yield. In a subsequent study, the authors demonstrated that the yield of hydrogen could be significantly greater (by $36.94 \%$ ) if the P. agglomerans BH-18 strain is used in a mixed culture with a Candida tropicalis BH-6 salt-tolerant strain, which had been isolated from the same mangrove ecosystem [168].

Conclusion. In the light of the above-cited reports, $P$. agglomerans appears to be a valuable bioremediator that could be efficiently used for the removal of different pollutants from the living environment, in some cases even for the acquisition of an alternative source of cheap energy.

\section{Production of the cryoprotective protein, other potential applications}

Production of the cryoprotective protein. In the preceding article [3] there was described the ice nucleation activity of P. agglomerans causing damage to plants, which also has some positive implications. The bacterium protects itself against self-induced decrease of temperature by the production of an anti-freeze cryoprotective protein. Koda et al. [169] have isolated from the cell mass of P. agglomerans IFO12686 ice nucleating strain a protein exhibiting extremely high cryoprotective activity that could be used for the protection of plants and/or food products. This was a novel monomer, heatstable protein with a molecular mass of 29,000 , protecting the freeze-labile enzymes against freezing-thawing denaturation.

Production of a potential bio-indicator. Another potential application of Pantoea agglomerans was indicated by Fujikawa and Akimoto [170], who isolated a unique strain of this bacterium producing a deep blue pigment. The production of the pigment was temperature-dependant and observed between $10-30^{\circ} \mathrm{C}$. Most probably it was regulated by the abovedescribed quorum sensing system. The authors determined the optimal conditions for the pigment production and suggested a potential use of the strain as a biological timetemperature indicator (TTI) for the management of foods and storage of clinical materials at low temperatures [170].

\section{Genetic variability and problems related to the European Union Directive}

Phylogenetic analysis performed by Delétoile et al. [171] revealed that the Pantoea genus is highly diverse, and this versatility was recently confirmed by Walterson and Stavrinides [6]. According to De Maayer et al. [172], this is associated with the acquisition and maintenance of plasmids, in particular the Large Pantoea Plasmid (LPP-1), described as 'an important driver of the biological, ecological and lifestyle diversification observed among the Pantoea species'. Because of the large variability of Pantoea isolates, it is assumed that they cannot be accurately assigned to species based on metabolic profiling $[173,174]$. Nevertheless, the results obtained by Delétoile et al. [171], Völksch et al. [4], and Nadarasah and Stavrinides [5], suggested that clinical and plant-associated $P$. agglomerans strains do not form distinct populations, and might possess indistinguishable virulence potential. Rezzonico et al. [173, $174]$ expressed an opinion that the use of P. agglomerans to combat fire blight should not be hampered by the European Union ban that was imposed because of the classification of this bacterium as a biosafety level 2 organism. This classification was based on reports of cases of opportunistic infections which, according to the cited authors, are doubtful because of the misidentification of causative strains. Although the authors are absolutely right concerning the nonsense of this ban, the essentials of the matter seem rather different.

Firstly, the strains of $P$. agglomerans and related species should, without any doubt, be classified as biosafety level 2 organisms, essentially not because of accidental infections, but because of the important occupational hazard due to potential inhalation exposure to strong endotoxins and allergens produced by Pantoea strains (most probably also by those used as biocontrol agents), particularly in agricultural occupations. Although the current European Directive 2000/54/EC [175] on work-related risks addresses not 'infectious' but 'biological agents at work' (which must be understood as infectious and/or allergenic and/or toxic agents of biological origin), nevertheless, the content of this Directive does not adhere to the promise implicit in title. Regrettably, the content and attached list of harmful biological agents are outdated and confined only to infectious agents, and do not meet the requirements of contemporary science [176]. 


\section{Pantoea agglomerans: benefits for humans, animals and plants}

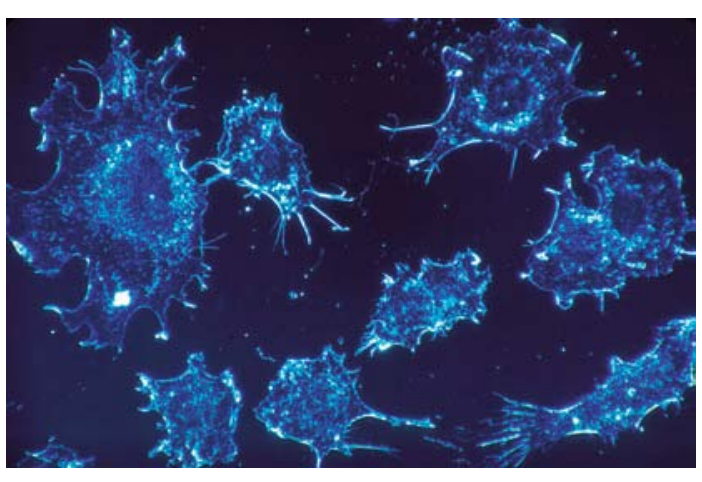

Curing tumors and other diseases
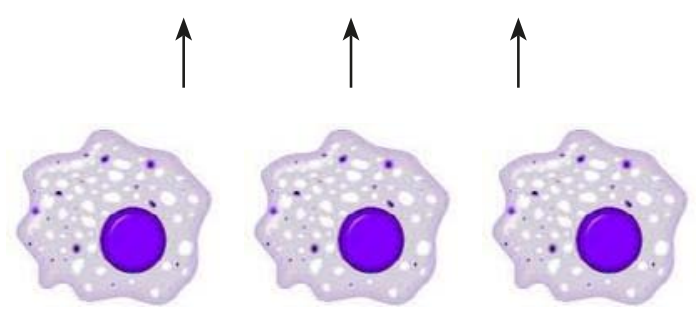

Macrophage activation by

P. agglomerans LPS

Maintenance of homeostasis

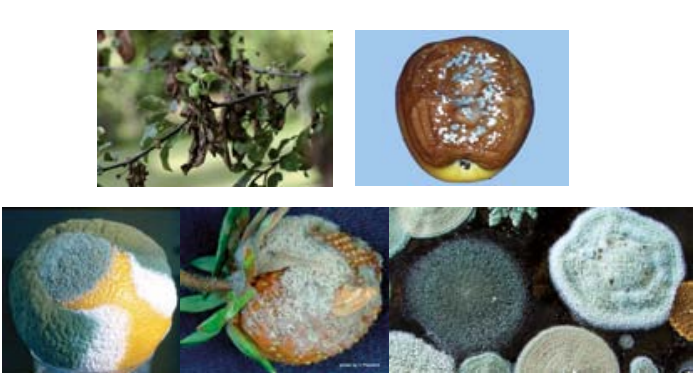

Combating plant pathogens

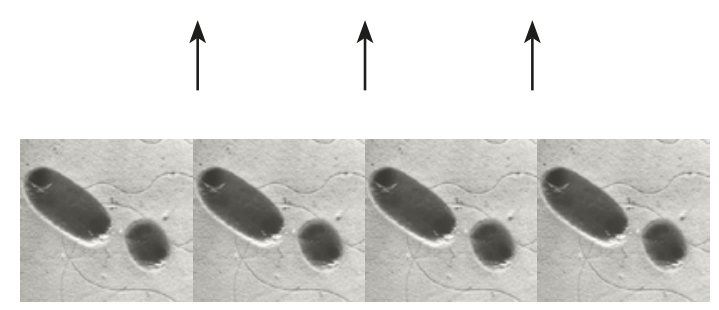

Production of antibiotics, successful competition, stimulation of systemic resistance of plants. As a result: reduction of the use of agrochemicals.

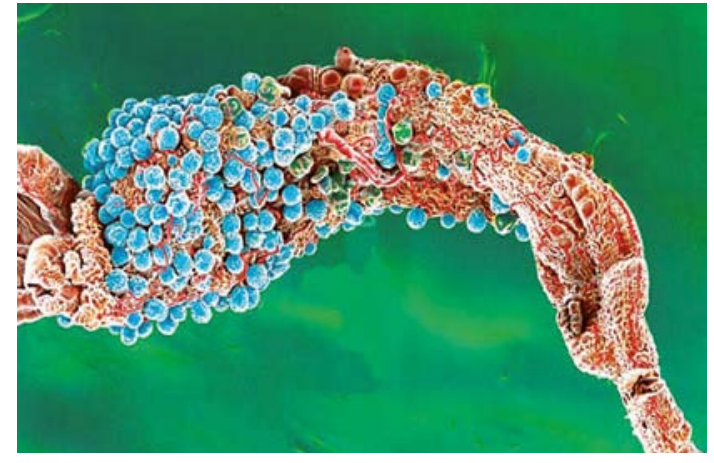

Killing malaria parasites in mosquito gut

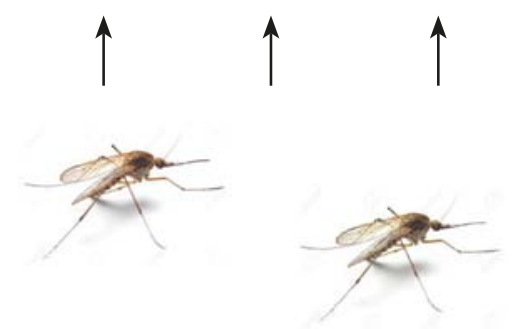

Paratransgenesis: introduction of transformed P. agglomerans bacteria into wild populations of Anopheles mosquitoes

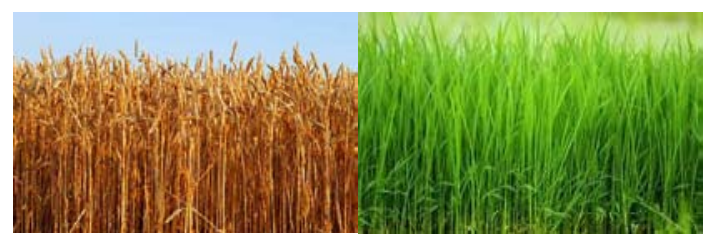

Promotion of the growth of wheat, rice and other crops

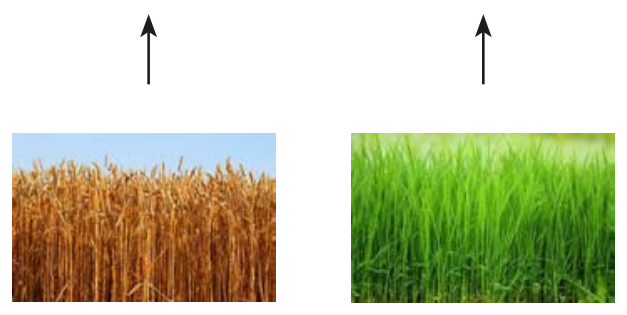

Promotion of plant growth by: fixation of atmospheric nitrogen, making available soil phosphorus by phytate degradation and phosphate solubilization, production of phytohormones, indole acetic acid and enzymes, induction of salt tolerance. 


\section{Pantoea agglomerans: benefits for environment - bioremediation}

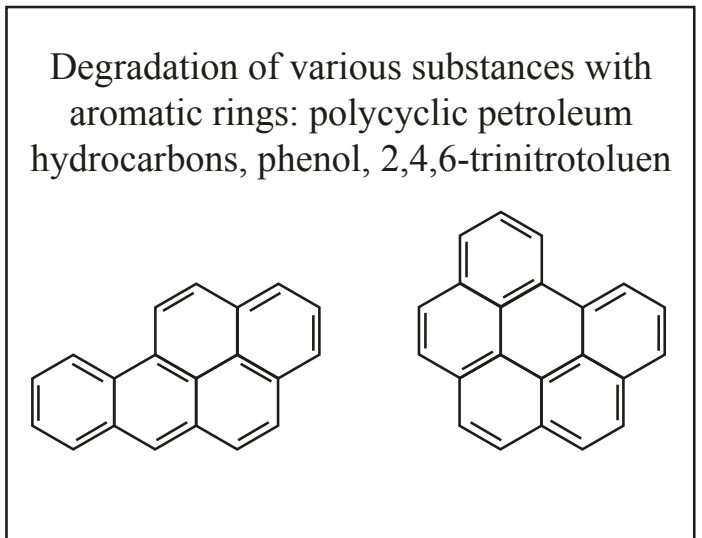

Biofilm formed by P. agglomerans can hinder migration of toxic metal and metalloids nanoparticles downwards soil.

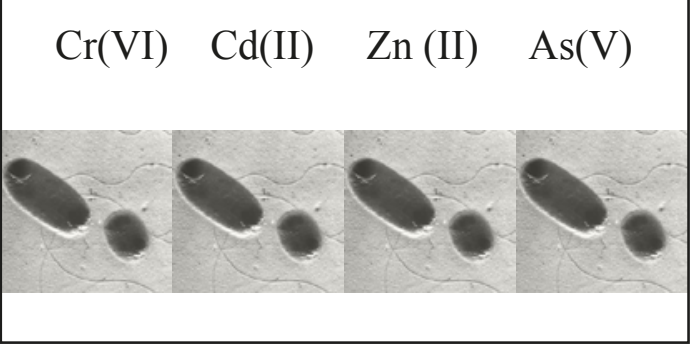

Reduction of toxic metals and metalloids

$\begin{array}{lll}\mathrm{Cr}(\mathrm{VI}) & \mathrm{Fe}(\mathrm{III}) & \mathrm{Mn}(\mathrm{IV}) \\ \mathrm{Cd}(\mathrm{II}) & \mathrm{Cu}(\mathrm{II}) & \mathrm{Pb}(\mathrm{II}) \\ \mathrm{Co}(\mathrm{II}) & \mathrm{Ni}(\mathrm{II}) & \mathrm{Pd}(\mathrm{II}) \\ \mathrm{Zn}(\mathrm{II}) & \mathrm{Hg}(\mathrm{II}) & \mathrm{As}(\mathrm{V})\end{array}$

Degradation of waste of plant origin: exceptional ability for the degradation of rice straw and lignin with a potential for use in industry or as a renewable energy source.

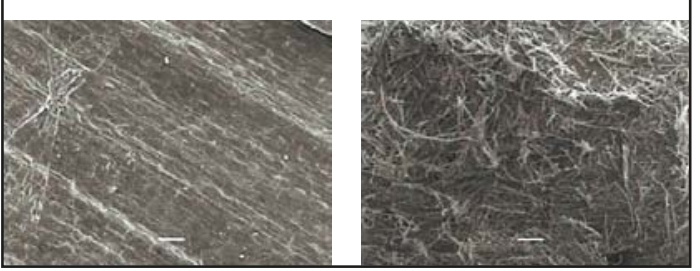

Figure 6. Pantoea agglomerans benefits for the environment. Photo of degradation of rice straw created on the basis of Figure 4, according to Xiong et al. (151).

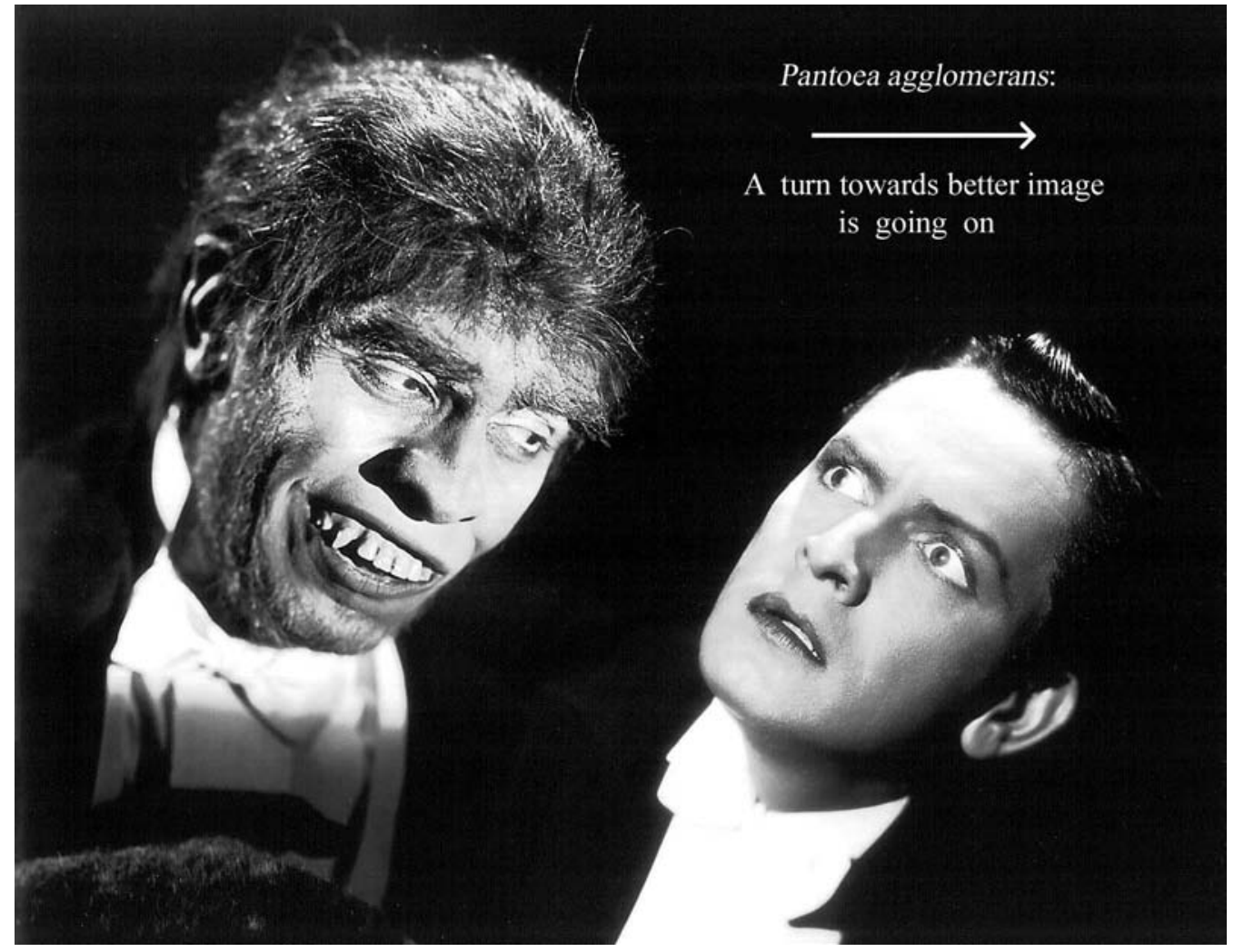

Figure 7. Dr. Jekyll \& Mr. Hyde. Photo from the 1920 silent film classic, as an analogy to the Pantoea agglomerans story. A turn towards a better image of this bacterium is progressing. 
Secondly, the classification of Pantoea as a biosafety level 2 organism (incidentally, the obsolete classification using 1-4 levels should be replaced by one that is more accurate and logical, using $0-5$ levels) should not lead to restrictions on its use, not only as a biocontrol anti-fire blight agent, but also as an anti-cancer supportive drug, an efficient plant growth promoter, a biofertilizer or bioremediator. Quite simply, the outdated regulations should be changed. The new legislation should authorize the use of Pantoea biopreparations under the following conditions:

1) If possible, the Pantoea biopreparations should not be used in the form of an aerosol; however, if so used, the workers handling these preparations must be protected by efficient respirators or masks preventing the respiration of toxic and/or allergenic nanoparticles.

2) The workers using the biopreparations must use gloves as protection from accidental skin perforation and infection.

3) The immunocompromised persons must not be engaged in the application of the Pantoea biopreparations.

\section{In conclusion:}

1. Pantoea agglomerans should be classified as a biosafety level 2 organism.

2. Its use for biocontrol and other purposes should be permitted if safety precautions are provided.

\section{Concluding remarks: The Strange Case of Dr. Jekyll and Mr. Hyde in the Microcosmos}

The novel by the Scottish writer Robert Louis Stevenson (1850-1894) entitled The Strange Case of Dr. Jekyll and Mr. Hyde [177] in which Dr. Jekyll, a kind and intelligent physician, turns into Mr. Hyde, an abominable monster, is a one of the best known stories about dual-personality. Although in the world of microorganisms one cannot speak about 'personality' the story of Pantoea agglomerans has some analogies with the Jekyll/Hyde case. In our story, an abominable bacterium causing occupational diseases due to the inhalation of organic dusts and opportunistic infections, appears as a beneficial agent protecting human health by the efficient treatment of tumours and other diseases, as well as by combating vector-borne diseases, increasing food supply by plant growth promotion and protection from pest and pathogens, and assuring a clean, human-friendly environment, by effective biodegradation (Figs. 5-6). Who Jekyll or Hyde - will be a winner in the fascinating Pantoea agglomerans story? The problem is not an easy one to solve, but in our understanding the answer will be: Jekyll! This turn of Pantoea agglomerans towards a better image (Fig. 7) is not a result of the positive evolution of this bacterium which cannot proceed in such a short time. Instead, it could be possible due, on one hand, to the fast progress in biotechnology, and on the other, on the increase in occupational safety. Although the strains of many other bacterial species could be more efficient in some positive traits exhibited by P. agglomerans (for example, nitrogen fixation or metal reduction), the unique, truly exceptional ubiquitous occurrence of this bacterium associated with an extremely strong metabolism and easy adaptation to changing environmental conditions, speaks for its broad use in biotechnology, which may contribute to the improvement of our health and quality of life, hopefully in the not too distant future.

\section{Acknowledgements}

The authors express their thanks to following: to the John Wiley \& Sons, Inc. for permission to reproduce Figure 3 from the article by Gond et al. [137], and Figure 4 from the article by Xiong et al. [151], both Figures protected by Copyright (C) John Wiley \& Sons, All Rights Reserved; to the International Institute of Anticancer Research for permission to reproduce Figure 1 from the article by Wakame et al. [48]; to the Editors of Genetics and Molecular Research for permission to reproduce Figure 2 from the article by Pandolfi et al. [92].

\section{REFERENCES}

1. Dutkiewicz J, Mackiewicz B, Lemieszek MK, Golec M, Milanowski J. Pantoea agglomerans: a mysterious bacterium of evil and good. Part I. Deleterious effects: Dust-borne endotoxins and allergens - focus on cotton dust. Ann Agric Environ Med. 2015; 22(4): 576-588.

2. Dutkiewicz J, Mackiewicz B, Lemieszek MK, Golec M, Skórska C, GóraFlorek A, Milanowski J. Pantoea agglomerans: a mysterious bacterium of evil and good. Part II. Deleterious effects: Dust-borne endotoxins and allergens - focus on grain dust, other agricultural dusts and wood dust. Ann Agric Environ Med. 2016; 23(1): 110-133.

3. Dutkiewicz J, Mackiewicz B, Lemieszek MK, Golec M, Milanowski J. Pantoea agglomerans: a mysterious bacterium of evil and good. Part III. Deleterious effects: Infections of humans, animals and plants. Ann Agric Environ Med. 2016; 23(2): 197-205.

4. Völksch B, Thon S, Jacobsen ID, Gube M. Polyphasic study of plant- and clinic-associated Pantoea agglomerans strains reveals indistinguishable virulence potential. Infect Genet Evol. 2009; 9(6): 1381-1391.

5. Nadarasah G, Stavrinides J. Quantitative evaluation of the hostcolonizing capabilities of the enteric bacterium Pantoea using plant and insect hosts. Microbiology. 2014; 160: 602-615.

6. Walterson AM, Stavrinides J. Pantoea: insights into a highly versatile and diverse genus within the Enterobacteriaceae. FEMS Microbiol Rev. 2015; 39: 968-984.

7. Chalupowicz L, Manulis-Sasson S, Itkin M, Sacher A, Sessa G, Barash I. Quorum-sensing system affects gall development incited by Pantoea agglomerans pv. gypsophilae. Mol Plant Microbe Interact. 2008; 21(8): 1094-1105.

8. Kohchi C, Inagawa H, Nishizawa T, Yamaguchi T, Nagai S, Soma G. Applications of lipopolysaccharide derived from Pantoea agglomerans (IP-PA1) for health care based on macrophage network theory. J Biosci Bioeng. 2006; 102(6): 485-496.

9. Jiang J, Wu S, Wang J, Feng Y. AHL-type quorum sensing and its regulation on symplasmata formation in Pantoea agglomerans YS19. J Basic Microbiol. 2015; 55: 607-616.

10. Smith DD, Kirzinger MW, Stavrinides J. Draft genome sequence of the antibiotic-producing cystic fibrosis isolate Pantoea agglomerans Tx10. Genome Announc. 2013; 1(5). pii: e00904-13. doi: 10.1128/ genomeA.00904-13.

11. Kempf H-J, Wolf G. Erwinia herbicola as a biocontrol agent of Fusarium culmorum and Puccinia recondita f. sp. tritici on wheat. Phytopathology. 1989; 79: 990-994.

12. Greiner M, Winkelmann G. Fermentation and isolation of herbicolin A, a peptide antibiotic produced by Erwinia herbicola strain A 111. Appl Microbiol Biotechnol. 1991; 34(5): 565-569.

13. Kamber T, Lansdell TA, Stockwell VO, Ishimaru CA, Smits TH, Duffy B. Characterization of the biosynthetic operon for the antibacterial peptide herbicolin in Pantoea vagans biocontrol strain C9-1 and incidence in Pantoea species. Appl Environ Microbiol. 2012; 78(12): 4412-4419.

14. Wright SA, Zumoff CH, Schneider L, Beer SV. Pantoea agglomerans strain EH318 produces two antibiotics that inhibit Erwinia amylovora in vitro. Appl Environ Microbiol. 2001; 67(1): 284-292.

15. Vanneste JL, Cornish DA, Yu J, Voyle MD. The peptide antibiotic produced by Pantoea agglomerans Eh252 is a microcin. Acta Hortic. 2002; 590: 285-290.

16. Shoji J, Sakazaki R, Hattori T, Matsumoto K, Uotani N, Yoshida T. Isolation and characterization of agglomerins A, B, C and D. J Antibiot (Tokyo). 1989; 42(12): 1729-1733.

17. Pidot SJ, Coyne S, Kloss F, Hertweck C. Antibiotics from neglected bacterial sources. Int J Med Microbiol. 2014; 304(1): 14-22. 
18. Sammer UF, Reiher K, Spiteller D, Wensing A, Völksch B. Assessment of the relevance of the antibiotic 2-amino-3-(oxirane-2,3-dicarboxamido)propanoyl-valine from Pantoea agglomerans biological control strains against bacterial plant pathogens. Microbiologyopen. 2012; 1(4):438-449.

19. Giddens SR, Feng Y, Mahanty HK. Characterization of a novel phenazine antibiotic gene cluster in Erwinia herbicola Eh1087. Mol Microbiol. 2002; 45(3): 769-783.

20. Giddens SR, Bean DC. Investigations into the in vitro antimicrobial activity and mode of action of the phenazine antibiotic D-alanylgriseoluteic acid. Int J Antimicrob Agents. 2007; 29(1): 93-97.

21. Lim JA, Lee DH, Kim BY, Heu S. Draft genome sequence of Pantoea agglomerans R190, a producer of antibiotics against phytopathogens and foodborne pathogens. J Biotechnol. 2014; 188C: 7-8. doi: 10.1016/j. jbiotec.2014.07.440.

22. McCarthy EF. The toxins of William B. Coley and the treatment of bone and soft-tissue sarcomas. Iowa Orthopaed J. 2006; 26: 154-158.

23. Nishizawa T, Inagawa $H$, Oshima $H$, Okutomi T, Tsukioka D, Iguchi M, Soma G-I, Mizuno D. Homeostasis as regulated by activated macrophage. I. Lipopolysaccharide (LPS) from wheat flour: isolation, purification and some biological activities. Chem Pharm Bull. (Tokyo) 1992; 40: 479-483.

24. Kasugai H, Ishiyama J, Imai I, Fukuma E, Miyajima N, Kano N, Yamakawa T, Goto S, Kera J, Takeuchi S, et al. A case report of far advanced gastric cancer with multiple liver metastasis (H3) treated with transarterial intermittent chemotherapy and intradermal administration of low molecular lipopolysaccharide (LPSp) extracted from Pantoea agglomerans. Gan To Kagaku Ryoho. 1995; 22(11): 1690 1693 (in Japanese)

25. Iwamoto I, Goto S, Kera J, Soma G, Takeuchi S, Nagata Y. Mechanistic analysis of high antitumour effect of intradermal administration of lipopolysaccharide from Pantoea agglomerans. Med Oncol. 1996; 13(2): 103-109.

26. Kohchi C, Inagawa H, Nishizawa T, Yamaguchi T, Nagai S, Soma G. Applications of lipopolysaccharide derived from Pantoea agglomerans (IP-PA1) for health care based on macrophage network theory. J Biosci Bioeng. 2006; 102(6): 485-496.

27. Inagawa H, Nishizawa T, Yoshioka N, Taniguchi Y, Kohchi C, Soma G-I. Preventative and therapeutic potential of lipopolysaccharide derived from edible Gram-negative bacteria to various diseases. Curr Drug Ther. 2008; 2: 26-32.

28. Hebishima T, Matsumoto Y, Watanabe G, Soma GI, Kohchi C, Taya K, Hayashi Y, Hirota Y. Original oral administration of Immunopotentiator from Pantoea agglomerans 1 (IP-PA1) improves the survival of B16 melanoma-inoculated model mice. Exp Animals. 2011; 60 (2P): 101-109.

29. Mizuno D, Soma G. Oral or percutaneous administration of lipopolysaccharide of small molecular size may cure various intractable diseases: a new version of Coley's toxin. Mol Biother. 1992; 4(4): 166-169.

30. Inagawa $H$, Nishizawa $T$, Takagi $K$, Goto S, Soma G, Mizuno D. Antitumour mechanism of intradermal administration of lipopolysaccharide. Anticancer Res. 1997; 17(3C): 1961-1964.

31. Inagawa $H$, Nishizawa T, Noguchi K, Minamimura M, Takagi K, Goto S, Soma G, Mizuno D. Anti-tumour effect of lipopolysaccharide by intradermal administration as a novel drug delivery system. Anticancer Res. 1997; 17(3C): 2153-2158.

32. Dutkiewicz J, Skórska C, Burrell R, Szuster-Ciesielska A, Sitkowska J. Immunostimulative effects of repeated inhalation exposure to microvesicle-bound endotoxin of Pantoea agglomerans. Ann Agric Environ Med. 2005; 12: 289-294.

33. Śpiewak R, Dutkiewicz J. In vitro study of pro-inflammatory and antitumour properties of microvesicles from bacterial cell wall of Pantoea agglomerans. Ann Agric Environ Med. 2008; 15: 153-161.

34. Hino M, Kohchi C, Nishizawa T, Yoshida A, Nakata K, Inagawa $H$ Hori H, Makino K, Terada H, Soma G-I. Innate-immune therapy for lung carcinoma based on tissue-macrophage activation with lipopolysaccharide. Anticancer Res. 2005; 25: 3747-3754.

35. Goto S, Sakai S, Kera J, Suma Y, Soma GI, Takeuchi S. Intraderma administration of lipopolysaccharide in treatment of human cancer. Cancer Immunol Immunother. 1996; 42(4): 255-261.

36. Hebishima T, Matsumoto Y, Watanabe G, Soma G, Kohchi C, Taya K, Hayashi Y, Hirota Y. Protective effects of the immunopotentiator from Pantoea agglomerans 1 on chemotherapeutic agent-induced macrophage growth inhibition. Anticancer Res. 2010; 30(6): 2033-2040.

37. Inagawa $H$, Nishizawa T, Tsukioka D, Suda T, Chiba Y, Okutomi T, Morikawa A, Soma GI, Mizuno D. Homeostasis as regulated by activated macrophage. II. LPS of plant origin other than wheat flour and their concomitant bacteria. Chem Pharm Bull (Tokyo). 1992; 40(4): 994-997.
38. Inagawa H, Saitoh F, Iguchi M, Nishizawa T, Okutomi T, Morikawa A, Soma GI, Mizuno D. Homeostasis as regulated by activated macrophage. III. Protective effect of LPSw (lipopolysaccharide (LPS) of wheat flour) on gastric ulcer in mice as compared with those of other LPS from various sources. Chem Pharm Bull. (Tokyo) 1992; 40(4): 998-1000.

39. Hebishima T, Matsumoto Y, Watanabe G, Soma G, Kohchi C, Taya K, Hayashi Y, Hirota Y. Recovery from immunosuppressionrelated disorders in humans and animals by IP-PA1, an edible lipopolysaccharide. Anticancer Res. 2010; 30(8): 3113-3118.

40. Inagawa $\mathrm{H}$, Kohchi $\mathrm{C}$, Soma G. Oral administration of lipopolysaccharides for the prevention of various diseases: benefit and usefulness. Anticancer Res. 2011; 31(7): 2431-2436.

41. Inagawa H, Nishizawa T, Yoshioka N, Taniguchi Y, Kohchi C, Soma G-I. Preventative and therapeutic potential of lipopolysaccharide derived from edible Gram-negative bacteria to various diseases. Curr Drug Ther. 2008; 2: 26-32.

42. Nakata K, Inagawa H, Soma G: Lipopolysaccharide IP-PA1 from Pantoea agglomerans prevents suppression of macrophage function in stress-induced diseases. Anticancer Res. 2011; 31(7): 2437-2440.

43. Kadowaki T, Inagawa H, Kohchi C, Hirashima M, Soma G. Functional characterization of lipopolysaccharide derived from symbiotic bacteria in rice as a macrophage-activating substance. Anticancer Res. 2011; 31(7): 2467-2476.

44. Shimada M, Kadowaki T, Taniguchi Y, Inagawa H, Okazaki K, Soma $\mathrm{G}$. The involvement of $\mathrm{O}$-antigen polysaccharide in lipopolysaccharide in macrophage activation. Anticancer Res. 2012; 32(6): 2337-2341.

45. Kadowaki T, Ohno S, Taniguchi Y, Inagawa H, Kohchi C, Soma G. Induction of nitric oxide production in RAW264.7 cells under serumfree conditions by $\mathrm{O}$-antigen polysaccharide of lipopolysaccharide. Anticancer Res. 2013; 33(7): 2875-2879.

46. Yoshida A, Kohchi C, Inagawa H, Nishizawa T, Soma G. Improvement of allergic dermatitis via regulation of the Th1/Th2 immune system balance by macrophages activated with lipopolysaccharide derived from Pantoea agglomerans (IP-PA1). Anticancer Res. 2009; 29(11): 4867-4870.

47. von Mutius E, Braun-Fahrländer C, Schierl R, Riedler J, Ehlermann S, Maisch S, Waser M, Nowak D. Exposure to endotoxin or other bacterial components might protect against the development of atopy. Clin Exp Allergy. 2000; 30: 1230-1234.

48. Wakame K, Komatsu K, Inagawa H, Nishizawa T. Immunopotentiator from Pantoea agglomerans prevents atopic dermatitis induced by Dermatophagoides farinae extract in NC/Nga mouse. Anticancer Res. 2015; 35(8): 4501-4508.

49. Okutomi T, Nishizawa T, Inagawa H, Morikawa A, Takeuchi S, Soma G, Mizuno D. Homeostasis as regulated by activated macrophage. IV. Analgesic effect of LPSw, a lipopolysaccharide of wheat flour. Chem Pharm Bull. (Tokyo) 1992; 40: 1001-1003.

50. Kamei J, Iwamoto Y, Suzuki T, Misawa M, Kasuya Y, Okutomi T, Soma G, Mizuno D. Suppression of hyperalgesia in streptozotocin-induced diabetic mice by a lipopolysaccharide from Pantoea agglomerans. Biol Pharm Bull. 1994; 17(5): 632-634.

51. Okutomi T, Nishizawa T, Inagawa H, Soma G, Minami M, Satoh M, Mizuno D. Inhibition of morphine dependence by a lipopolysaccharide from Pantoea agglomerans. Eur Cytokine Netw. 1992; 3(4): 417-420.

52. Okutomi T, Suzuki T. Immunomodulator as medicine for morphine and cocaine dependence. Especially effect of LPS. Yakugaku Zasshi. 1995; 115(1): 42-51 (in Japanese).

53. Suzuki T, Funada M, Sugano Y, Misawa M, Okutomi T, Soma G, Mizuno D. Effects of a lipopolysaccharide from Pantoea agglomerans on the cocaine-induced place preference. Life Sci. 1994; 54(6): PL75-80.

54. Fukasaka M, Asari D, Kiyotoh E, Okazaki A, Gomi Y, Tanimoto T, Takeuchi O, Akira S, Hori M. A lipopolysaccharide from Pantoea agglomerans is a promising adjuvant for sublingual vaccines to induce systemic and mucosal immune responses in mice via TLR4 pathway. PLoS One. 2015; 10(5): e0126849. doi: 10.1371/journal.pone.0126849.

55. Komori T, Saito K, Sawa N, Shibasaki Y, Kohchi C, Soma G, Inagawa $\mathrm{H}$. Innate immunity activated by oral administration of LPSp is phylogenetically preserved and developed in broiler chickens. Anticancer Res. 2015; 35(8): 4461-4466.

56. Hebishima T, Matsumoto Y, Soma G, Kohchi C, Watanabe G, Taya K, Hayashi Y, Hirota Y. Immune recovery effects of immunopotentiator from Pantoea agglomerans 1 (IP-PA1) on low antibody productions in response to Salmonella enteritidis vaccine and sheep red blood cells in dexamethasone-treated stressed chicken models. J Vet Med Sci. 2010; 72(4): 435-442.

57. Takahashi $Y$, Kondo M, Itami T, Honda T, Inagawa $H$, Nishizawa $T$, Soma GI, Yokomizo Y. Enhancement of disease resistance against 
penaeid acute viraemia and induction of virus-inactivating activity in haemolymph of kuruma shrimp, Penaeus japonicus, by oral administration of Pantoea agglomerans lipopolysaccharide (LPS). Fish Shellfish Immunol. 2000; 10(6): 555-558.

58. Kadowaki T, Yasui Y, Takahashi Y, Kohchi C, Soma G, Inagawa H. Comparative immunological analysis of innate immunity activation after oral administration of wheat fermented extract to teleost fish. Anticancer Res. 2009; 29(11): 4871-4877.

59. Carbajal-González MT, Fregeneda-Grandes JM, Suárez-Ramos S, Rodríguez Cadenas F, Aller-Gancedo JM. Bacterial skin flora variation and in vitro inhibitory activity against Saprolegnia parasitica in brown and rainbow trout. Dis Aquat Organ. 2011; 96(2):125-135.

60. Suzuki Y, Kobayashi A, Nishizawa T, Inagawa H, Morikawa A, Soma G-I, Mizuno D. Homeostasis as regulated by activated macrophage. VI. Protective effect of LPSw (a lipopolysaccharide from wheat flour) against acute infection by Toxoplasma gondii in mice. Chem Pharm Bull (Tokyo). 1992; 40(5): 1266-1267.

61. Wang J, Leng J, Wang QH. Mechanism of the effect of LPSp on the production of anti-HBs in mice. Xi Bao Yu Fen Zi Mian Yi Xue Za Zhi. 2007; 23(6): 559-561 (in Chinese).

62. Mushtaq H, Bakht J, Bacha N. Screening of the novel colicinogenic gram-negative rods against pathogenic Escherichia coli O157:H7. Indian J Med Microbiol. 2015; 33(5): 67-72.

63. Rafat A Philip K, Muniandy S. A novel source of bioactive compounds: endophytic bacteria isolated from Centella asiatica. J Pure Appl Microbiol. 2012; 6(1): 11-20.

64. Okutomi T, Nishizawa T, Inagawa H, Takano T, Morikawa A, Soma G.-I, Mizuno, D. Homeostasis as regulated by activated macrophage. VII. Suppression of serum cholesterol level by LPSw (a lipopolysaccharide from wheat flour) in WHHL (Watanabe heritable hyperlipidemic) rabbit. Chem Pharm Bull. (Tokyo) 1992; 40: 1268-1270.

65. Iguchi M, Inagawa H, Nishizawa T, Okutomi T, Morikawa A, Soma G I, Mizuno D. Homeostasis as regulated by activated macrophage. V. Suppression of diabetes mellitus in non-obese diabetic mice by LPSw (a lipopolysaccharide from wheat flour). Chem Pharm Bull. (Tokyo) 1992; 40: 1004-1006.

66. Nakata K, Nakata Y, Inagawa H, Nakamoto T, Yoshimura H, Soma G. Pantoea agglomerans lipopolysaccharide maintains bone density in premenopausal women: a randomized, double-blind, placebocontrolled trial. Food Sci Nutr. 2014; 2(6): 638-646.

67. Suzuki J, Nishizawa T, Inagawa H, Okutomi T, Morikawa A, Soma G, Mizuno D. Homeostasis as regulated by activated macrophage. IX. Enhancement effect of LPSw (a lipopolysaccharide from wheat flour) on hen egg-laying and breaking strength of eggshell. Chem Pharm Bull. 1992; 40: 1274-1276.

68. Nicoletti G, Corbella M, Jaber O, Marone P, Scevola D, Faga A. Nonpathogenic microflora of a spring water with regenerative properties. Biomed Rep. 2015; 3(6): 758-762.

69. Medrano EG, Esquivel JF, Bell AA. Transmission of cotton seed and boll rotting bacteria by the southern green stink bug (Nezara viridula L.). J Appl Microbiol. 2007; 103(2): 436-444.

70. Dutta B, Barman AK, Srinivasan R, Avci U, Ullman DE, Langston DB, Gitaitis RD. Transmission of Pantoea ananatis and P. agglomerans, causal agents of center rot of onion (Allium cepa), by onion thrips (Thrips tabaci) through feces. Phytopathology. 2014; 104(8): 812-819.

71. Valiente Moro C, Tran FH, Raharimalala FN, Ravelonandro P, Mavingui P. Diversity of culturable bacteria including Pantoea in wild mosquito Aedes albopictus. BMC Microbiol. 2013; 13: 70. doi: 10.1186/1471-2180-13-70.

72. Bisi DC, Lampe DJ. Secretion of anti-Plasmodium effector proteins from a natural Pantoea agglomerans isolate by using PelB and HlyA secretion signals. Appl Environ Microbiol. 2011; 77(13): 4669-4675.

73. Wang S, Ghosh AK, Bongio N, Stebbings KA, Lampe DJ, Jacobs-Lorena M. Fighting malaria with engineered symbiotic bacteria from vector mosquitoes. Proc Natl Acad Sci U S A. 2012; 109(31): 12734-12739.

74. Maleki-Ravasan N, Oshaghi MA, Hajikhani S, Saeidi Z, Akhavan AA, Gerami-Shoar M, Shirazi H, Yakhchali B, Rassi Y, Afshar D. Aerobic microbial community of insectary population of Phlebotomus papatasi. J Arthropod-Borne Dis. 2014; 8(1): 69-81.

75. Heerman M, Weng JL, Hurwitz I, Durvasula R, Ramalho-Ortigao M. Bacterial infection and immune responses in Lutzomyia longipalpis sand fly larvae midgut. PLoS Negl Trop Dis. 2015; 9(7): e0003923. doi: 10.1371/journal.pntd.0003923.

76. Quecine MC, Araújo WL, Tsui S, Parra JR, Azevedo JL, PizziraniKleiner AA. Control of Diatraea saccharalis by the endophytic Pantoea agglomerans 33.1 expressing crylAc7. Arch Microbiol. 2014; 196(4): $227-234$.
77. Dillon RJ, Vennard CT, Charnley AK. A note: gut bacteria produce components of a locust cohesion pheromone. J Appl Microbiol. 2002; 92(4): 759-763.

78. MacCollom GB, Lauzon CR, Sjogren RE, Meyer WL, Olday F. Association and attraction of blueberry maggot fly Curran (Diptera: Tephritidae) to Pantoea (Enterobacter) agglomerans. Environ Entomol. 2009; 38(1): 116-120.

79. Arora AK, Forshaw A, Miller TA, Durvasula R. A delivery system for field application of paratransgenic control. BMC Biotechnol. 2015; 15: 59. doi: 10.1186/s12896-015-0175-3.

80. Morales H, Sanchis V, Usall J, Ramos AJ, Marín S. Effect of biocontrol agents Candida sake and Pantoea agglomerans on Penicillium expansum growth and patulin accumulation in apples. Int J Food Microbiol. 2008; 122(1-2): 61-67.

81. Pusey PL, Stockwell VO, Reardon CL, Smits TH, Duffy B. Antibiosis activity of Pantoea agglomerans biocontrol strain E325 against Erwinia amylovora on apple flower stigmas. Phytopathology. 2011; 101(10): 1234-1241.

82. Sturz A, Matheson B. Populations of endophytic bacteria which influence host-resistance to Erwinia-induced bacterial soft rot in potato tubers. Plant Soil. 1996; 184: 265-271.

83. Hsieh TF, Huang HC, Erickson RS. Biological control of bacterial wilt of bean using a bacterial endophyte, Pantoea agglomerans. J Phytopathol. 2005; 10 : 608-614.

84. Sadik S, Mazouz H, Bouaichi A, Benbouazza A, Achbani EH. Biological control of bacterial onion diseases using a bacterium, Pantoea agglomerans 2066-7. Int J Science Research. 2013; 4(1): 103-111.

85. Hsieh SPY, Buddenhagen IW. Suppressing effects of Erwinia herbicola on infection by Xanthomonas oryzae and on symptom development in rice. Phytopathology. 1974; 64:1182-1185.

86. Braun-Kiewnick A, Jacobsen BJ, Sands DC. Biological control of Pseudomonas syringae pv. syringae, the causal agent of basal kernel blight of barley, by antagonistic Pantoea agglomerans. Phytopathology. 2000; 90(4): 368-375.

87. Pasichnyk LA, Hvozdiak RI, Khodos SF. Interaction of Pantoea agglomerans with the agent of basal bacteriosis of wheat. Mikrobiol Z. 2005; 67(1): 32-40 (in Ukrainian).

88. Han DY, Coplin DL, Bauer WD, Hoitink HA. A rapid bioassay for screening rhizosphere microorganisms for their ability to induce systemic resistance. Phytopathology. 2000; 90(4): 327-332.

89. Ortmann I, Moerschbacher BM. Spent growth medium of Pantoea agglomerans primes wheat suspension cells for augmented accumulation of hydrogen peroxide and enhanced peroxidase activity upon elicitation. Planta. 2006; 224(4): 963-970.

90. Ortmann I, Conrath U, Moerschbacher BM. Exopolysaccharides of Pantoea agglomerans have different priming and eliciting activities in suspension-cultured cells of monocots and dicots. FEBS Lett. 2006; 580(18): 4491-4494

91. Romanenko VM, Alimov DM. Ability of representatives of Pantoea agglomerans, as well as Bacillus subtilis and some Pseudomonas species to suppress the development of phytopathogenic bacteria and micromycetes in regulating plant growth. Mikrobiol Z. 2000; 62(4): 29-37 (in Ukrainian).

92. Pandolfi V, Jorge EC, Melo CM, Albuquerque AC, Carrer H. Gene expression profile of the plant pathogen Fusarium graminearum under the antagonistic effect of Pantoea agglomerans. Genet Mol Res. 2010; 9(3): 1298-1311.

93. Schisler DA, Slininger PJ, Bothast RJ. 1997. Effects of antagonist cell concentration and two-strain mixtures on biological control of Fusarium dry rot of potatoes. Phytopathology. 87: 177-183.

94. Adetuyi FC. Studies of the antifungal compounds produced by Erwinia herbicola. Indian J Pathol Microbiol. 1990; 33(1): 48-52.

95. Rosales AM, Vantomme R, Swings J, de Ley J, Mew TW. Identification of some bacteria from paddy antagonistic to several rice fungal pathogens. J Phytopathol. (Berl.) 1993; 138(3): 189-208.

96. Sartori M, Nesci A, Formento Á, Etcheverry M. Selection of potential biological control of Exserohilum turcicum with epiphytic microorganisms from maize. Rev Argent Microbiol. 2015; 47(1): 62-71.

97. Vasebi Y, Alizadeh A, Safaie N. Pantoea agglomerans ENA1 as a biocontrol agent of Macrophomia phaseolina and growth enhancer of soybean. J Crop Prot. 2015; 4(1): 43-57.

98. Gunasinghe R, Ikiriwatte C, Karunaratne A. The use of Pantoea agglomerans and Flavobacterium sp to control banana pathogens. J Hortic Sci Biotech. 2004; 79: 1002-1006.

99. Chernin L, Ismailov Z, Haran S, Chet I. Chitinolytic Enterobacter agglomerans antagonistic to fungal plant pathogens. Appl Environ Microbiol. 1995; 61(5): 1720-1726. 
100. Verhagen B, Trotel-Aziz P, Jeandet P, Baillieul F, Aziz A. Improved resistance against Botrytis cinerea by grapevine-associated bacteria that induce a prime oxidative burst and phytoalexin production. Phytopathology. 2011; 101(7): 768-777.

101. Zhang W, Han DY, Dick WA, Davis KR, Hoitink HAJ. Compost and compost water extract-induced systemic acquired resistance in cucumber and Arabidopsis. Phytopathology. 1998; 88: 450-455.

102. Vanneste J, Yu J, Reglinski T. Biocontrol agent Pantoea agglomerans strain NZ501 induces a resistance-like response in kiwifruit and tobacco cells. Acta Hortic. 2002; 590: 279-283.

103. Nunes C, Usall J, Teixidó N, Viñas I. Biological control of postharvest pear diseases using a bacterium, Pantoea agglomerans CPA-2. Int J Food Microbiol. 2001; 70(1-2): 53-61.

104. Nunes C, Usall J, Teixidó N, Fons E, Viñas I. Post-harvest biological control by Pantoea agglomerans (CPA-2) on Golden Delicious apples. J Appl Microbiol. 2002; 92(2): 247-255.

105. Teixidó N, Usall J, Palou L, Asensio A, Nunes C, Viñas I. Improving control of green and blue molds of oranges by combining Pantoea agglomerans (CPA-2) and sodium bicarbonate. Eur J Plant Pathol. 2001; 107: 658-694.

106. Plaza P, Usall J, Smilanick JL, Lamarca N, Viñas I. Combining Pantoea agglomerans (CPA-2) and curing treatments to control established infections of Penicillium digitatum on lemons. J Food Prot. 2004; 67(4): 781-786.

107. Bonaterra A, Mari M, Casalini L, Montesinos E. Biological control of Monilinia laxa and Rhizopus stolonifer in postharvest of stone fruit by Pantoea agglomerans EPS125 and putative mechanisms of antagonism. Int J Food Microbiol. 2003; 84: 93-104.

108. Kotan R, Dikbas N, Bostan H. Biological control of post harvest disease caused by Aspergillus flavus on stored lemon fruits. Afr J Biotechnol. 2009; 8(2): 209-214.

109. Zhang X, Zhang Y, Zhang Z, Zhang S, Han J, Liu H. Identification of Pantoea agglomerans XM2 with biocontrol activity against postharvest pear black spot. Wei Sheng Wu Xue Bao. 2014; 54(6): 648-655 (in Chinese).

110. Bardin SD, Huang HC, Liu L, Yanke LJ. Control, by microbial seed treatment, of damping off caused by Pythium sp. on canola, safflower, dry pea, and sugar beet. Can J Plant Pathol. 2003; 25(3): 268-275.

111. Munif A, Hallmann J, Sikora RA. The influence of endophytic bacteria on Meloidogyne incognita infection and tomato plant growth. JISSAAS. 2013; 19(2): 68-74.

112. Gvozdiak RI, Iakovleva LM. Pantoea agglomerans - pathogen of Elytrigia repens and Arrhenatherum elatius diseases. Mikrobiol Z. 2007; 69(1): 61-67 (in Russian).

113. Son HJ, Park GT, Cha MS, Heo MS. Solubilization of insoluble inorganic phosphates by a novel salt- and $\mathrm{pH}$-tolerant Pantoea agglomerans $\mathrm{R}-42$ isolated from soybean rhizosphere. Bioresour Technol. 2006; 97(2): 204-210.

114. Malboobi MA, Owlia P, Behbahani M, Sarokhani E, Sara Moradi S, Yakhchali B, Deljou A, Heravi KM. Solubilization of organic and inorganic phosphates by three highly efficient soil bacterial isolates. World J Microbiol Biotechnol. 2009; 25: 1471-1477.

115. Malboobi MA, Behbahani M, Madani H, Owlia P, Deljou A, Yakhchali B, Moradi M, Hassanabadi H. Performance evaluation of potent phosphate solubilizing bacteria in potato rhizosphere. World J Microbiol Biotechnol. 2009; 25: 1479-1484.

116. Sulbarán M, Pérez E, Ball MM, Bahsas A, Yarzábal LA. Characterization of the mineral phosphate-solubilizing activity of Pantoea agglomerans MMB051 isolated from an iron-rich soil in southeastern Venezuela (Bolívar State). Curr Microbiol. 2009; 58(4): 378-383.

117. Lakshmanan V, Shantharaj D, Li G, Seyfferth AL, Janine Sherrier D, Bais HP. A natural rice rhizospheric bacterium abates arsenic accumulation in rice (Oryza sativa L.). Planta. 2015; 242(4): 1037-1050.

118. Khalimi K, Suprapta DN, Nitta Y. Effect of Pantoea agglomerans on growth promotion and yield of rice. Agric Sci Res J. 2012; 2(5): $240-249$.

119. Amellal N, Burtin G, Bartoli F, Heulin T. Colonization of wheat roots by an exopolysaccharide-producing Pantoea agglomerans strain and its effect on rhizosphere soil aggregation. Appl Environ Microbiol. 1998; 64(10): 3740-3747.

120. Mishra A, Chauhan PS, Chaudhry V, Tripathi M, Nautiyal CS. Rhizosphere competent Pantoea agglomerans enhances maize (Zea mays) and chickpea (Cicer arietinum L.) growth, without altering the rhizosphere functional diversity. Antonie Van Leeuwenhoek. 2011; 100(3): 405-413.

121. Dastager SG, Deepa CK, Puneet SC, Nautiyal CS, Pandey A. Isolation and characterization of plant growth-promoting strain Pantoea NII-
186 from Western Ghat forest soil, India. Lett Appl Microbiol. 2009; 49(1): 20-25.

122.Silini-Chérif H, Silini A, Ghoul M, Yadav S. Isolation and characterization of plant growth promoting traits of a rhizobacteria: Pantoea agglomerans lma2. Pak J Biol Sci. 2012; 15(6): 267-276.

123. Kleeberger A, Castorph H, Klingmüller W. The rhizosphere microflora of wheat and barley with special reference to gram-negative bacteria. Arch Microbiol. 1983; 136: 306-311.

124. Greiner R. Purification and properties of a phytate-degrading enzyme from Pantoea agglomerans. Protein J. 2004; 23(8): 567-576.

125. Suleimanova AD, Danilova YV, Greiner R, Sharipova MR. A new intracellular phytase of enterobacteria: isolation and characterization. Russ J Bioorganic Chem. 2013; 39 (4): 378-383.

126. Suleimanova AD, Toymentseva AA, Boulygina EA, Kazakov SV, Mardanova AM, Balaban NP, Sharipova MR. High-quality draft genome sequence of a new phytase-producing microorganism Pantoea sp. 3.5.1. Stand Genom Sci. 2015; 10: 95, doi: 10.1186/s40793-015$0093-y$

127. Suleimanova AD, Beinhauer A, Valeeva LR, Chastukhina IB, Balaban NP, Shakirov EV, Greiner R, Sharipova MR. Novel glucose1-phosphatase with high phytase activity and unusual metal ion activation from soil bacterium Pantoea sp. strain 3.5.1. Appl Environ Microbiol. 2015; 81(19): 6790-6799.

128. Feng Y, Shen D, Song W. Rice endophyte Pantoea agglomerans YS19 promotes host plant growth and affects allocations of host photosynthates. J Appl Microbiol. 2006; 100(5): 938-945.

129. Scholz-Seidel C, Ruppel S. (1992) Nitrogenase- and phytohormone activities of Pantoea agglomerans in culture and their reflection in combination with wheat plants. Zbl Mikrobiol. 1992; 147: 319-328.

130. Ruppel S, Hecht-Buchholz C, Remus R, Ortmann U, Schmelzer R. Settlement of diazotrophic, phytoeffective bacterial strain Pantoea agglomerans on and within winter wheat: An investigation using ELISA and transmission electron microscopy. Plant Soil. 1992; 145: 261-273.

131. Remus R, Ruppel S, Jacob HJ, Hecht-Buchholz C, Merbach W. Colonization behaviour of two enterobacterial strains on cereals. Biol Fert Soils. 2000; 30: 550-557.

132. Egamberdiyeva D, Höflich $G$. Influence of growth-promoting bacteria on the growth of wheat in different soils and temperatures. Soil Biol Biochem. 2003; 35: 973-978.

133. Verma SC, Ladha JK, Tripathi AK. Evaluation of plant growth promoting and colonization ability of endophytic diazotrophs from deep water rice. J Biotechnol. 2001; 91(2-3): 127-141.

134. Miao Y, Zhou J, Chen C, Shen D, Song W, Feng Y. In vitro adsorption revealing an apparent strong interaction between endophyte Pantoea agglomerans YS19 and host rice. Curr Microbiol. 2008; 57: 547-551.

135. Banik A, Mukhopadhaya SK, Dangar TK. Characterization of N2 fixing plant growth promoting endophytic and epiphytic bacterial community of Indian cultivated and wild rice (Oryza spp.) genotypes. Planta. 2016; 243(3): 799-812.

136. Loiret FG, Ortega E, Kleiner D, Ortega-Rodés P, Rodés R, Dong Z. A putative new endophytic nitrogen-fixing bacterium Pantoea sp. from sugarcane. J Appl Microbiol. 2004; 97(3): 504-511.

137. Gond SK, Torres MS, Bergen MS, Helsel Z, White JF Jr. Induction of salt tolerance and up-regulation of aquaporin genes in tropical corn by rhizobacterium Pantoea agglomerans. Lett Appl Microbiol. 2015; 60(4): 392-399.

138. Quecine MC, Araújo WL, Rossetto PB, Ferreira A, Tsui S, Lacava PT, Mondin M, Azevedo JL, Pizzirani-Kleiner AA. Sugarcane growth promotion by the endophytic bacterium Pantoea agglomerans 33.1. Appl Environ Microbiol. 2012; 78(21): 7511-7518.

139. Andreote FD, Rossetto PB, Souza LC, Marcon J, Maccheroni W Jr, Azevedo JL, Araújo WL. Endophytic population of Pantoea agglomerans in citrus plants and development of a cloning vector for endophytes. J Basic Microbiol. 2008; 48(5): 338-346.

140. Ferreira A, Quecine MC, Lacava PT, Oda S, Azevedo JL, Araújo WL. Diversity of endophytic bacteria from Eucalyptus species seeds and colonization of seedlings by Pantoea agglomerans. FEMS Microbiol Lett. 2008; 287(1): 8-14.

141. De Lima Procópio RE, Araújo WL, Andreote FD, Azevedo JL. Characterization of a small cryptic plasmid from endophytic Pantoea agglomerans and its use in the construction of an expression vector. Genet Mol Biol. 2011; 34(1): 103-109.

142. Asis CA Jr, Adachi K. Isolation of endophytic diazotroph Pantoea agglomerans and nondiazotroph Enterobacter asburiae from sweet potato stem in Japan. Lett Appl Microbiol. 2004; 38(1): 19-23.

143. Jasim B, Anish MC, Shimil V, Jyothis M, Radhakrishnan EK. Studies on plant growth promoting properties of fruit-associated bacteria from 
Elettaria cardamomum and molecular analysis of ACC deaminase gene. Appl Biochem Biotechnol. 2015; 177(1): 175-189.

144. de Almeida Lopes KB, Carpentieri-Pipolo V, Oro TH, Pagliosa ES, Degrassi G. Culturable endophytic bacterial communities associated with field grown soybean. J Appl Microbiol. 2016; 120(3): 740-755.

145. Dursun A, Ekinci M, Dönmez MF. Effects of foliar application of plant growth promoting bacterium on chemical contents, yield and growth of tomato (Lycopersicon esculentum L.) and cucumber (Cucumis sativus L.). Pak J Bot. 2010; 42(5): 3349-3356.

146. Dastager SG, Deepa CK, Pandey A. Isolation and characterization of high- strength phenol-degrading novel bacterium of the Pantoea genus. Biorem J. 2009; 13: 171-179.

147. Abboud M.M, Khleifat KM, Batarseh M, Tarawneh KA, Al-Mustafa A, Al-Madadhah M. Different optimization conditions required for enhancing the biodegradation of linear alkylbenzosulfonate and sodium dodecyl sulphate surfactants by novel consortium of Acinetobacter calcoaceticus and Pantoea agglomerans. Enzyme Microb Technol. 2007; 41: 432-439.

148. Zou LD, Lu DN, Liu Z. Pathways for degrading TNT by Thu-Z: a Pantoea sp. strain. Appl Biochem Biotechol. 2012; 168: 1976-1988.

149. Pepi M, Lampariello LR, Altieri R, Esposito A, Perra G, Renzi M, Lobianco A, Feola A. et al. Tannic acid degradation by bacterial strains Serratia spp. and Pantoea sp. Isolated from olive mill waste mixtures. Int Biodeter Biodegr. 2010; 64: 73-80.

150. Pileggi M, Pileggi SAV, Olchanheski LR, Silva PAG, Gonzalez AMM, Koskinen WC, Barber B, Sadowsky MJ. Isolation of mesotrionedegrading bacteria from aquatic environments in Brazil. Chemosphere. 2012; 86: 1127-1132.

151. Xiong XQ, Liao HD, Ma JS, Liu XM, Zhang LY, Shi XW, Yang XL, Lu $\mathrm{XN}$, Zhu YH. Isolation of a rice endophytic bacterium, Pantoea sp. Sd-1, with ligninolytic activity and characterization of its rice straw degradation ability. Lett Appl Microbiol. 2014; 58(2): 123-129.

152. Jacobucci DFC, de Godoy Oriani MR, Durrant LR. Reducing COD level on oily effluent by utilizing biosurfactant-producing bacteria. Braz Arch Biol Techn. 2009; 52(4): 1037-1042.

153. Zhang SY, Wang QF, Xie SG. Molecular characterization of phenanthrene-degrading methanogenic communities in leachatecontaminated aquifer sediment. Int J Environ Sci Technol. 2012; 9: 705-712.

154. Vasileva-Tonkova E, Gesheva V. Biosurfactant production by antarctic facultative anaerobe Pantoea sp. during growth on hydrocarbons. Curr Microbiol. 2007; 54(2): 136-141.

155. Yousaf S, Ripka K, Reichenauer TG, Andria V, Afzal M, Sessitsch A. Hydrocarbon degradation and plant colonization by selected bacterial strains isolated from Italian ryegrass and birdsfoot trefoil. J Appl Microbiol. 2010; 109(4): 1389-1401.

156. Afzal M, Yousaf S, Reichenauer TG, Sessitsch A. The inoculation method affects colonization and performance of bacterial inoculant strains in the phytoremediation of soil contaminated with diesel oil. Int J Phytoremediation. 2012; 14(1): 35-47.

157. Arslan M, Afzal M, Amin I, Iqbal S, Khan QM. Nutrients can enhance the abundance and expression of alkane hydroxylase CYP153 gene in the rhizosphere of ryegrass planted in hydrocarbon-polluted soil. PLoS One. 2014; (10): e111208. doi: 0.1371/journal.pone.0111208.

158. Tara N, Afzal M, Ansari TM, Tahseen R, Iqbal S, Khan QM. Combined use of alkane-degrading and plant growth-promoting bacteria enhanced phytoremediation of diesel contaminated soil. Int J Phytoremediation. 2014; 16(7-12): 1268-1277.

159. Boucher D, Laffaire JB, Jaziri F, David C, Biderre-Petit C, Duquenne P, Peyretaillade E, Peyret P. Bacterial community composition of biological degreasing systems and health risk assessment for workers. Microb Ecol. 2011; 62(4): 868-881.
160. Francis CA, Obraztsova AY, Tebo BM. Dissimilatory metal reduction by the facultative anaerobe Pantoea agglomerans SP1. Appl Environ Microbiol. 2000; 66(2): 543-548.

161. Wu CY, Li FB, Zhou SG, Zhuang L, Wang YQ. Isolation and characterization of a facultative anaerobe Pantoea agglomerans MFC-3 and its humic substance-and Fe(III) - respiring activity. Huan Jing Ke Xue. 2010; 31(1): 237-242 (in Chinese).

162. Ozdemir G, Ceyhan N, Ozturk T, Akirmak F, Cosar T. Biosorption of chromium(VI), cadmium(II) and copper(II) by Pantoea sp. TEM18. Chem Engin J. 2004; 102: 249-253.

163. Zaets I, Kramarev S, Kozyrovska N. Inoculation with a bacterial consortium alleviates the effect of cadmium overdose in soybean plants. Cent Eur J Biol. 2010; 5(4): 481-490.

164. Pishchik VN, Provorov NA, Vorobyov NI, Chievskaya EP, Safronova VI, Tuev AN, Kozhemyakov AP. Interactions between plants and associated bacteria in soils contaminated with heavy metals. Microbiology. 2009; 7: 785-793.

165. Tian H, Shi Q, Jing C. Arsenic biotransformation in solid waste residue: comparison of contributions from bacteria with arsenate and iron reducing pathways. Environ Sci Technol. 2015; 49(4): 2140-2146.

166. Kurlanda-Witek H, Ngwenya BT, Butler IB. The influence of biofilms on the mobility of bare and capped zinc oxide nanoparticles in saturated sand and glass beads. J Contam Hydrol. 2015; 179: 160-170.

167. Zhu D, Wang G, Qiao H, Cai J. Fermentative hydrogen production by the new marine Pantoea agglomerans isolated from the mangrove sludge. Int J Hydrogen Energy. 2008; 33(21): 6116-6123.

168. Zhu D, Ma Y, Wang G, Pan G. Identification of Candida tropicalis BH-6 and synergistic effect with Pantoea agglomerans $\mathrm{BH}-18$ on hydrogen production in marine culture. Appl Biochem Biotechnol. 2015; 175(5): 2677-2688.

169. Koda N, Asaeda T, Yamade K, Kawahara H, Obata H. A novel cryoprotective protein (CRP) with high activity from the ice-nucleating bacterium, Pantoea agglomerans IFO12686. Biosci Biotechnol Biochem. 2001; 65(4): 888-894.

170. Fujikawa H, Akimoto R. New blue pigment produced by Pantoea agglomerans and its production characteristics at various temperatures. Appl Environ Microbiol. 2011; 77(1): 172-178.

171. Delétoile A, Decré D, Courant S, Passet V, Audo J, Grimont P, Arlet G, Brisse S. Phylogeny and identification of Pantoea species and typing of Pantoea agglomerans strains by multilocus gene sequencing. J Clin Microbiol. 2009; 47(2): 300-310.

172. De Maayer P, Chan WY, Blom J, Venter SN, Duffy B, Smits TH, Coutinho TA. The large universal Pantoea plasmid LPP-1 plays a major role in biological and ecological diversification. BMC Genomics. 2012; 13:625. http://www.biomedcentral.com/1471-2164/13/625.

173. Rezzonico F, Stockwell VO, Tonolla M, Duffy B, Smits TH. Pantoea clinical isolates cannot be accurately assigned to species based on metabolic profiling. Transpl Infect Dis. 2012; 14(2): 220-221.

174. Rezzonico F, Smits TH, Duffy B. Misidentification slanders Pantoea agglomerans as a serial killer. J Hosp Infect. 2012; 81(2): 137-139.

175. Directive 2000/54/EC of the European Parliament and of The Council of 18 September 2000 on the protection of workers from risks related to exposure to biological agents at work (seventh individual directive within the meaning of Article 16(1) of Directive 89/391/EEC). Brussels 2000.

176. Dutkiewicz J. Directive 2000/54/WE and strategy of the measurement of the biological agents levels in occupational settings. Podst Met Oceny Środ Pracy. 2004; 3(41): 9-16 (in Polish).

177. Robert Louis Stevenson. The Strange Case of Dr. Jekyll and Mr. Hyde. First publication in any form 1886. First downloadable PDF edition 1998. Composed electronically by Anthony Atkielski. Anthony's Home Page, http://www.atkielski.com 1998. 